\title{
Heterogeneous sulfate aerosol formation mechanisms during wintertime Chinese haze events: air quality model assessment using observations of sulfate oxygen isotopes in Beijing
}

\author{
Jingyuan Shao ${ }^{1,2}$, Qianjie Chen ${ }^{2,3}$, Yuxuan Wang ${ }^{4}$, Xiao Lu ${ }^{1}$, Pengzhen $\mathrm{He}^{5}$, Yele Sun ${ }^{6}$, Viral Shah ${ }^{2,7}$, \\ Randall V. Martin ${ }^{8}$, Sajeev Philip ${ }^{9}$, Shaojie Song ${ }^{7}$, Yue Zhao ${ }^{10}$, Zhouqing Xie ${ }^{5}$, Lin Zhang ${ }^{1}$, and Becky Alexander ${ }^{2}$ \\ ${ }^{1}$ Laboratory for Climate and Ocean-Atmosphere Studies, Department of Atmospheric and Oceanic Sciences, \\ School of Physics, Peking University, Beijing 100871, China \\ ${ }^{2}$ Department of Atmospheric Sciences, University of Washington, Seattle, WA 98195, USA \\ ${ }^{3}$ Department of Chemistry, University of Michigan, Ann Arbor, MI 48109, USA \\ ${ }^{4}$ Department of Earth and Atmospheric Sciences, University of Houston, Houston, TX 77204, USA \\ ${ }^{5}$ Anhui Province Key Laboratory of Polar Environment and Global Change, School of Earth and Space Sciences, \\ University of Science and Technology of China, Hefei 230026, China \\ ${ }^{6}$ State Key Laboratory of Atmospheric Boundary Physics and Atmospheric Chemistry, Institute of Atmospheric Physics, \\ Chinese Academy of Sciences, Beijing 100029, China \\ ${ }^{7}$ School of Engineering and Applied Sciences, Harvard University, Cambridge, MA 02138, USA \\ ${ }^{8}$ Department of Physics and Atmospheric Science, Dalhousie University, Halifax, Nova Scotia, Canada \\ ${ }^{9}$ NASA postdoctoral program, NASA Ames Research Center, Moffett Field, CA 94035, USA \\ ${ }^{10}$ School of Environmental Science and Engineering, Shanghai Jiao Tong University, Shanghai 200240, China
}

Correspondence: Becky Alexander (beckya@uw.edu), Lin Zhang (zhanglg@pku.edu.cn) and Zhouqing Xie (zqxie@ustc.edu.cn)

Received: 27 December 2018 - Discussion started: 14 January 2019

Revised: 6 April 2019 - Accepted: 17 April 2019 - Published: 8 May 2019

\begin{abstract}
Air quality models have not been able to reproduce the magnitude of the observed concentrations of fine particulate matter $\left(\mathrm{PM}_{2.5}\right)$ during wintertime Chinese haze events. The discrepancy has been at least partly attributed to low biases in modeled sulfate production rates, due to the lack of heterogeneous sulfate production on aerosols in the models. In this study, we explicitly implement four heterogeneous sulfate formation mechanisms into a regional chemical transport model, in addition to gas-phase and incloud sulfate production. We compare the model results with observations of sulfate concentrations and oxygen isotopes, $\Delta^{17} \mathrm{O}\left(\mathrm{SO}_{4}^{2-}\right)$, in the winter of 2014-2015, the latter of which is highly sensitive to the relative importance of different sulfate production mechanisms. Model results suggest that heterogeneous sulfate production on aerosols accounts for about $20 \%$ of sulfate production in clean and polluted conditions, partially reducing the modeled low bias in sulfate concentrations. Model sensitivity studies in comparison with the
\end{abstract}

$\Delta^{17} \mathrm{O}\left(\mathrm{SO}_{4}^{2-}\right)$ observations suggest that heterogeneous sulfate formation is dominated by transition metal ion-catalyzed oxidation of $\mathrm{SO}_{2}$.

\section{Introduction}

China has experienced rapid urbanization and industrialization in recent years, which has led to significant growth in concentration of $\mathrm{PM}_{2.5}$ (particulate matter with aerodynamic diameter less than $2.5 \mu \mathrm{m}$ ) in Chinese megacities, particularly in Beijing (the capital of China) and the surrounding area (Zhang et al., 2015, 2016; Wang et al., 2014). Extensive studies consistently show high $\mathrm{PM}_{2.5}$ levels in winter due to increased coal combustion for heating and a stable atmospheric boundary layer (Sun et al., 2014, 2016; Z. Liu et al., 2015; Ma et al., 2017). The frequency and concentration 
of $\mathrm{PM}_{2.5}$ pollution negatively impacts human health and atmospheric visibility and results in economic losses (Gao et al., 2015; Lelieveld, et al., 2015; Zhang et al., 2015). The Chinese government has implemented a series of policies to improve air quality, and, as a result, the annual average $\mathrm{PM}_{2.5}$ concentration in Beijing decreased by $\sim 20 \%$ from 2013 to 2017 (Sun et al., 2016; Zheng et al., 2018; Beijing Environment Protection Agency, 2018; Chinese State Council, 2013). Despite these improvements, $\mathrm{PM}_{2.5}$ concentrations in Beijing still regularly exceed the Chinese National Ambient Air Quality Standards (CNAAQS, $35 \mathrm{\mu g} \mathrm{m}^{-3}$ annual average) (Sun et al., 2016; Zhang et al., 2016; Beijing Environment Protection Agency, 2018).

Sulfate is one of the most important components of $\mathrm{PM}_{2.5}$, representing $10 \%-30 \%$ of $\mathrm{PM}_{2.5}$ mass in eastern China (Huang et al., 2014; Zhang et al., 2013; Wang et al., 2014; Sun et al., 2016; Shi et al., 2017). Recent observations show that the sulfate mass fraction of $\mathrm{PM}_{2.5}$ increases during haze pollution periods, indicating that sulfate is a key driver for severe haze events (Wang et al., 2014, 2016; Cheng et al., 2016; G. Li et al., 2017). Previous simulations have shown that most models fail to predict severe haze pollution in Beijing, at least in part because of sulfate underestimation (Jiang et al., 2013; Park et al., 2014; Pozzer et al., 2012). Globally, sulfate production is dominated by the gas-phase oxidation of $\mathrm{SO}_{2}$ by $\mathrm{OH}$ and aqueous-phase oxidation of $\mathrm{S}(\mathrm{IV})\left(\mathrm{SO}_{2} \cdot \mathrm{H}_{2} \mathrm{O}+\mathrm{HSO}_{3}^{-}+\mathrm{SO}_{3}^{2-}\right)$ by $\mathrm{H}_{2} \mathrm{O}_{2}, \mathrm{O}_{3}$, and $\mathrm{O}_{2}$ catalyzed by transition metal ions (TMIs) in cloud droplets (Calvert and Stockwell, 1983; Schwartz, 1987; Harris et al., 2013; Alexander et al., 2012; Chen et al., 2018). Heterogeneous sulfate production, which refers to aqueousphase oxidation of $\mathrm{S}(\mathrm{IV})\left(\mathrm{SO}_{2} \cdot \mathrm{H}_{2} \mathrm{O}+\mathrm{HSO}_{3}^{-}+\mathrm{SO}_{3}^{2-}\right)$ on the surface of and/or within the bulk preexisting aerosols, is generally thought to be minor due to the low liquid water content of aerosols $\left(<10^{-9} \mathrm{~cm}^{3} \mathrm{~cm}^{-3}\right)$ compared to clouds $\left(10^{-8}\right.$ to $\left.10^{-6} \mathrm{~cm}^{3} \mathrm{~cm}^{-3}\right)$ (Jacob, 2000). However, recent studies have shown that traditional gas- and aqueous-phase chemistry in cloud droplets cannot explain rapid sulfate production observed during haze, suggesting missing sulfate formation mechanisms on aerosols in the models (Zheng et al., 2015; D. Chen et al., 2016; Zhang et al., 2015; Wang et al., 2014; Cheng et al., 2016; Huang et al., 2014). These missing sulfate formation mechanisms on aerosols include heterogeneous oxidation of $\mathrm{SO}_{2}$ by $\mathrm{NO}_{2}$ (Cheng et al., 2016; Wang et al., 2016, 2018; Gao et al., 2016; Zhang et al., 2015) and $\mathrm{O}_{2}$ catalyzed by TMIs (G. Li et al., 2017; Li et al., 2011) and via a free radical chain mechanism (Huie and Neta, 1984; Hung and Hoffman, 2015). The importance of these heterogeneous reactions remains highly uncertain, due in part to uncertainties regarding the aerosol liquid water content, $\mathrm{pH}$, and ionic strength, all of which impact heterogeneous reaction rates (Herrmann et al., 2015; Cheng et al., 2016). In particular, ambient aerosol $\mathrm{pH}$ cannot be directly measured, and thus represents a large source of uncertainty (Hennigan et al., 2015).
Previous studies have calculated a large range of aerosol $\mathrm{pH}$ values (3.4-7.8) in Beijing using a thermodynamic model (ISORROPIA-II) (Fountoukis and Nenes, 2007). He et al. (2018) noted that the large differences in calculated aerosol $\mathrm{pH}$ depended on whether they assume aerosols exist in a stable (Wang et al., 2016; He et al., 2018) or metastable state (Liu et al., 2017; Guo et al., 2017; He et al., 2018). A stable-state assumption allows for the simultaneous existence of solid and aqueous phases, while the metastable-state assumption allows for the existence of aqueous phase only by assuming salts to be supersaturated in aerosols (Fountoukis and Nenes, 2007). Aerosol $\mathrm{pH}$ values simulated assuming a stable state are near neutral ( $\mathrm{pH}$ of 7$)$, much higher than when assuming a metastable state ( $\mathrm{pH}$ of 4-5) during haze events in China (Guo et al., 2017; Liu et al., 2017; He et al., 2018). However, a recent study calculated an aerosol $\mathrm{pH}$ of around 4.6 during Chinese haze events for both the stable and metastable assumptions in ISORROPIA-II after fixing coding errors that impacted the stable-state assumption (Song et al., 2018). This casts doubt on the existence of neutral aerosol $\mathrm{pH}$ during Chinese haze events and thus the importance of the $\mathrm{NO}_{2}$ oxidation pathway, which is not important under acidic conditions. Other factors, such as an underestimate of $\mathrm{NH}_{3}$ emissions (Zhang et al., 2018) and $\mathrm{Ca}^{2+}$ concentrations in aerosols (Shen et al., 2016) and the lack of consideration of organic acids in aerosol $\mathrm{pH}$ calculations (Wang et al., 2018), add additional uncertainties in estimates of aerosol $\mathrm{pH}$ and thus sulfate production rates and mechanisms in Chinese haze events.

The oxygen isotopic composition $\Delta^{17} \mathrm{O}$ $\left(\approx \delta^{17} \mathrm{O}-0.52 \times \delta^{18} \mathrm{O}\right)$ of secondary sulfate $\left(\Delta^{17} \mathrm{O}\left(\mathrm{SO}_{4}^{2-}\right)\right)$ reflects the relative importance of different oxidation mechanisms in sulfate production because some of the oxidants transfer unique oxygen isotope signatures to the sulfate oxidation product (Savarino et al., 2000). Sulfate production via $\mathrm{S}(\mathrm{IV})$ oxidation by $\mathrm{O}_{3}$ and $\mathrm{H}_{2} \mathrm{O}_{2}$ leads to positive $\Delta^{17} \mathrm{O}\left(\mathrm{SO}_{4}^{2-}\right)$ values of $9.8 \%$ and $0.7 \%$, respectively, while all other oxidants lead to $\Delta^{17} \mathrm{O}\left(\mathrm{SO}_{4}^{2-}\right)$ at or near $0 \%$ (Table $\mathrm{S} 1$ in the Supplement) (Vicars and Savarino, 2014; Savarino and Thiemens, 1999; Lee and Schwartz, 1983; Holt et al., 1981; Dubey et al., 1997). Primary sulfate, both natural (dust and sea salt) and anthropogenic (coal and oil combustion), also has $\Delta^{17} \mathrm{O}\left(\mathrm{SO}_{4}^{2-}\right)$ values equal to $0 \%$ (Dominguez et al., 2008; Lee et al., 2001). Once formed, sulfate in the atmosphere does not undergo further isotope exchange. Surface observations around the world show that $\Delta^{17} \mathrm{O}\left(\mathrm{SO}_{4}^{2-}\right)$ ranges from $0 \%$ to $6 \%$ (Alexander et al., 2005, 2012; Q. Chen et al., 2016; Dominguez et al., 2008; Jenkins and Bao, 2006; Lee et al., 2001; Lee and Thiemens, 2001; McCabe et al., 2006; Patris et al., 2007; He et al., 2018; Ishino et al., 2017). Due to the large positive enrichment of sulfate formed from $\mathrm{O}_{3}$ oxidation $\left(\Delta^{17} \mathrm{O}\left(\mathrm{SO}_{4}^{2-}\right)=9.8 \%\right.$ ) and the strong $\mathrm{pH}$ dependence of 
this aqueous-phase reaction, $\Delta^{17} \mathrm{O}\left(\mathrm{SO}_{4}^{2-}\right)$ is highly sensitive to $\mathrm{pH}$.

In this work, we implement four heterogeneous reactions for sulfate formation (via $\mathrm{H}_{2} \mathrm{O}_{2}, \mathrm{O}_{3}, \mathrm{NO}_{2}$, and TMIs) into a global chemical transport model (GEOS-Chem) and compare the model results with observations of sulfate and $\mathrm{SO}_{2}$ concentrations and $\Delta^{17} \mathrm{O}\left(\mathrm{SO}_{4}^{2-}\right)$ in Beijing from October 2014 to January 2015. During this time period, Beijing held the Asia-Pacific Economic Cooperation (APEC) meeting from 5 to 11 November 2014. During and before APEC, $\mathrm{SO}_{2}$ emissions in Beijing and its surrounding regions decrease due to strict emission controls to improve air quality (Zhang et al., 2016; J. G. Liu et al., 2015). This paper is organized as follows. Section 2 describes the model simulations and the observations, and the method used to calculate heterogeneous sulfate production rates. Section 3 discusses model results with and without heterogeneous sulfate production considered in comparison with observed concentration and $\Delta^{17} \mathrm{O}\left(\mathrm{SO}_{4}^{2-}\right)$. Section 4 discusses and explains the differences between our results and observations. Section 5 summarizes the main conclusions.

\section{Methodology}

\subsection{GEOS-Chem model}

We use the three-dimensional GEOS-Chem chemical transport model nested-grid version v10-01 (http://www. geos-chem.org/, last access: 1 May 2019) to investigate sulfate formation mechanisms in Beijing, China, between 18 October 2014 and 17 January 2015 (Wang et al., 2004, 2013, 2014; Zhang et al., 2015, 2016). The model has a horizontal resolution of $1 / 4^{\circ}$ latitude by $5 / 16^{\circ}$ longitude over East Asia $\left(70-140^{\circ} \mathrm{E}, 15-55^{\circ} \mathrm{N}\right)$ and 47 vertical levels up to $0.01 \mathrm{hPa}(\approx 81 \mathrm{~km})$. In the boundary layer where most heterogeneous sulfate production occurs, the vertical layer thickness is $120-150 \mathrm{~m}$ for the first 12 model layers (below $1700 \mathrm{~m}$ altitude). The model is driven by assimilated meteorological data from the NASA Goddard Earth Observing System (GEOS-FP), which have a temporal resolution of $3 \mathrm{~h}$ ( $1 \mathrm{~h}$ for surface quantities and mixing depths).

The model utilizes the global anthropogenic emission inventory EDGAR v4.2 (EC-JRC/PBL, 2011, http://edgar. jrc.ec.europa.eu/, last access: 1 May 2019), overwritten by regional inventories such as the MIX Asian emission inventory over Asia (M. Li et al., 2017), EMEP over Europe (http://www.emep.int/index.html, last access: 1 May 2019), and NEI2011 over the US (https://www.epa. gov/air-emissions-inventories, last access: 1 May 2019). In particular, the MIX Asian emission inventory includes emissions of $\mathrm{SO}_{2}, \mathrm{NO}_{x}, \mathrm{CO}, \mathrm{NH}_{3}$ and non-methane volatile organic compounds (NMVOCs) at a spatial resolution of $0.25^{\circ} \times 0.25^{\circ}$ for the year 2010 (M. Li et al., 2017; Geng et al., 2017). Mineral dust aerosols are emitted in the model as described in Fairlie et al. (2007) and distributed in four size bins (radius of $0.1-1.0,1.0-1.8,1.8-3.0$, and 3.0-6.0 $\mu \mathrm{m}$ ). In addition to natural dust, our model includes anthropogenic dust (radius of $0.1-1.0 \mu \mathrm{m}$ ) released from anthropogenic activities such as road, residential, and commercial construction and combustion, following Phillip et al. (2017). Previous studies have suggested that anthropogenic dust accounts for about $25 \%$ of the $\mathrm{PM}_{2.5}$ mass fraction in Beijing (Zhang et al., 2015; Phillip et al., 2017).

The sulfate-nitrate-ammonium aerosol system is fully coupled to oxidant chemistry (Park et al., 2004), with aerosol $\mathrm{pH}$, ionic strength, and aerosol water content (AWC) calculated from the ISORROPIA-II thermodynamic equilibrium model (Fountoukis and Nenes, 2007) that was implemented into GEOS-Chem by Pye et al. (2009). In the standard model (Run_Std), sulfate is produced from gas-phase oxidation of $\mathrm{SO}_{2}$ by $\mathrm{OH}$, aqueous-phase oxidation of $\mathrm{S}(\mathrm{IV})$ $\left(=\mathrm{SO}_{2} \cdot \mathrm{H}_{2} \mathrm{O}+\mathrm{HSO}_{3}^{-}+\mathrm{SO}_{3}^{2-}\right)$ by $\mathrm{H}_{2} \mathrm{O}_{2}$ and $\mathrm{O}_{3}$ in cloud droplets, and heterogeneous oxidation on sea salt aerosols by $\mathrm{O}_{3}$ (Alexander et al., 2005). Primary anthropogenic emissions of sulfate constitute $3.1 \%$ of total anthropogenic sulfur emissions in China and $1.5 \%-3.5 \%$ elsewhere. Sulfate is removed from the atmosphere via dry (Zhang et al., 2001) and wet (Liu et al., 2001) deposition, with a global lifetime of about $4 \mathrm{~d}$ (Alexander et al., 2005).

We performed three simulations at high horizontal resolution $\left(1 / 4^{\circ} \times 5 / 16^{\circ}\right)$ and seven sensitivity simulations at low horizontal resolution $\left(4^{\circ} \times 5^{\circ}\right)$ to investigate sulfate formation mechanisms in Beijing, as summarized in Table 1. In the model simulation Run_TMI, we implemented the incloud TMI-catalyzed aqueous-phase S(IV) oxidation by $\mathrm{O}_{2}$ chemistry into the model, which is thought to be one of the most important sulfate formation pathways during Northern Hemisphere winter (Huang et al., 2014; Harris et al., 2013; Alexander et al., 2009; Sofen et al., 2011). The parameterization of TMI-catalyzed S(IV) oxidation in cloud for GEOS-Chem follows Alexander et al. (2009) but with a reduced solubility of trace metals $\mathrm{Fe}$ and $\mathrm{Mn}$ derived from natural dust (from $1 \%$ to $0.45 \%$ for $\mathrm{Fe}$ and from $50 \%$ to $5 \%$ for $\mathrm{Mn}$ ) to better match observations (Desboeufs et al., 2001, 2005; Chuang et al., 2005). In the model, Fe from natural dust $\left([\mathrm{Fe}]_{\text {nat }}\right)$ is $3.5 \%$ of total dust mass and $\mathrm{Mn}$ from natural dust $\left([\mathrm{Mn}]_{\mathrm{nat}}\right)$ is a factor of 50 lower than $[\mathrm{Fe}]_{\text {nat }}$ (Alexander et al., 2009). Anthropogenic Mn ([Mn $\left.]_{\mathrm{ant}}\right)$ and $\mathrm{Fe}\left([\mathrm{Fe}]_{\mathrm{ant}}\right)$ are scaled to the abundance of primary anthropogenic sulfate due to common sources and atmospheric lifetimes. [Mn $]_{\text {ant }}$ is $1 / 300$ of primary sulfate concentration and $[\mathrm{Fe}]_{\text {ant }}$ is 10 times that of $[\mathrm{Mn}]_{\mathrm{ant}}$ as described in Alexander et al. (2009). Only soluble $\mathrm{Fe}$ and $\mathrm{Mn}$ in the oxidation states $\mathrm{Fe}(\mathrm{III})$ and $\mathrm{Mn}$ (II) catalyze $\mathrm{S}(\mathrm{IV})$ oxidation. For Fe, we assume solubility of $10 \%$ for $[\mathrm{Fe}]_{\text {ant }}$ and $0.45 \%$ of $[\mathrm{Fe}]_{\text {nat }}$ in cloud water, respectively, with $10 \%$ in the form of $\mathrm{Fe}$ (III) during daytime and $90 \%$ at night. For Mn, we assume a solubility of $50 \%$ for $[\mathrm{Mn}]_{\mathrm{ant}}$ and $5 \%$ for $[\mathrm{Mn}]_{\text {nat }}$ in cloud water, respectively, with $100 \%$ in the form of Mn(II). After modifi- 
Table 1. Description of model simulations.

\begin{tabular}{lccll}
\hline Model run & $\begin{array}{c}\text { TMI- } \\
\text { catalysis } \\
\text { in clouds }\end{array}$ & $\begin{array}{c}\text { Heterogeneous } \\
\text { reactions }\end{array}$ & $\begin{array}{l}\text { Aerosol } \\
\mathrm{pH}\end{array}$ & $\begin{array}{l}\text { Horizontal } \\
\text { resolution }\end{array}$ \\
\hline Run_STD & $\mathrm{N}$ & $\mathrm{N}$ & $\mathrm{ISO}^{1}$ & $1 / 4^{\circ} \times 5 / 16^{\circ}$ and $4^{\circ} \times 5^{\circ}$ \\
Run_TMI & $\mathrm{Y}$ & $\mathrm{N}$ & ISO & $1 / 4^{\circ} \times 5 / 16^{\circ}$ and $4^{\circ} \times 5^{\circ}$ \\
Run_Het & Y & Y & ISO & $1 / 4^{\circ} \times 5 / 16^{\circ}$ and $4^{\circ} \times 5^{\circ}$ \\
\hline Sensitivity & simulations based on Run_Het & & \\
\hline Run_pH2 & Y & Y & 2 & $4^{\circ} \times 5^{\circ}$ \\
Run_pH3 & Y & Y & 3 & $4^{\circ} \times 5^{\circ}$ \\
Run_pH4 & Y & Y & 4 & $4^{\circ} \times 5^{\circ}$ \\
Run_pH5 & Y & Y & 5 & $4^{\circ} \times 5^{\circ}$ \\
Run_pH6 & Y & Y & 6 & $4^{\circ} \times 5^{\circ}$ \\
Run_pH7 & Y & Y & 7 & $4^{\circ} \times 5^{\circ}$ \\
Run_pH8 & Y & Y & 8 & $4^{\circ} \times 5^{\circ}$ \\
\hline
\end{tabular}

${ }^{1}$ ISO means that the aerosol $\mathrm{pH}$ was calculated by ISORROPIA II in the model assuming a metastable state.

${ }^{2}$ For the sensitivity simulations, aerosol $\mathrm{pH}$ was fixed to the stated prescribed value.

cation, the average aqueous-phase concentration of $\mathrm{Fe}(\mathrm{III})$ in cloud water during our studying period is $2.9 \mu \mathrm{M}$ and $\mathrm{Mn}(\mathrm{II})$ is $1.3 \mu \mathrm{M}$ in the model, which is consistent with previous work (Fe(III): 0.6-7.4 $\mu \mathrm{M}$; $\mathrm{Mn}(\mathrm{II}): 0.4-1.7 \mu \mathrm{M})$ (He et al., 2018; Shen et al., 2012; Guo et al., 2012; see Sect. S3 for more details).

In the model run Run_Het, we added four heterogeneous sulfate production mechanisms (via $\mathrm{H}_{2} \mathrm{O}_{2}, \mathrm{O}_{3}, \mathrm{NO}_{2}$, and TMIs) on aerosols into the model, in addition to TMIcatalyzed oxidation in clouds. Implementation of these reactions in the model is described in Sect. 2.2. In Run_Het, heterogeneous sulfate production on aerosols only occurs when relative humidity $(\mathrm{RH})$ is greater than $50 \%$, effectively assuming that aerosol water content is too low for sufficient heterogeneous sulfate production at $\mathrm{RH}<50 \%$. When $\mathrm{RH}<50 \%$, aerosols are assumed to remain crystallized until reaching the deliquescence relative humidity (DRH). This is consistent with observations in previous studies showing that sulfate production rates in Chinese haze are positively correlated with RH (Sun et al., 2013; Zhang et al., 2015; Wang et al., 2016). $\mathrm{Ca}^{2+}$ and $\mathrm{Mg}^{2+}$ cations from dust (both natural and anthropogenic) are included in the aerosol thermodynamic calculations (aerosol $\mathrm{pH}$, aerosol water content, ionic strength). We assume that $\mathrm{Ca}^{2+}$ and $\mathrm{Mg}^{2+}$ cations constitute $3.0 \%$ and $0.6 \%$ of the dust by mass, respectively, based on observations near East Asian dust source regions (Fairlie et al., 2010). In addition, we considered the impacts of acidity and ionic strength on TMI-catalyzed reaction rates following Cheng et al. (2016) (Table 2), since the ionic strength of aerosol liquid water can reach $20 \mathrm{M}$ during polluted periods (He et al., 2018; Herrmann et al., 2015). We performed seven sensitivity studies based on Run_Het but with prescribed values of aerosol $\mathrm{pH}$ to examine the dependence of model results on aerosol $\mathrm{pH}$ alone (Table 1).
For all model simulations, sulfate produced from each oxidation pathway is labeled as a separate "tracer" in the model with a corresponding $\Delta^{17} \mathrm{O}\left(\mathrm{SO}_{4}^{2-}\right)$ values (nine sulfate tracers in total, Table S1) as originally described in Alexander et al. (2005). Primary anthropogenic sulfate is also included as a separate tracer in the model with $\Delta^{17} \mathrm{O}=0 \%$ (Lee et al., 2002). The details for calculating $\Delta^{17} \mathrm{O}\left(\mathrm{SO}_{4}^{2-}\right)$ in the model are described in the Supplement (Text S1).

\subsection{Heterogeneous sulfate production on aerosols}

Heterogeneous S(IV) oxidation in the model occurs on all aerosol types, including sulfate-nitrate-ammonium, dust, black carbon, organic carbon, and sea salt aerosols. The heterogeneous sulfate production rate on aerosol $\left(P_{\text {het }}\right)$ is calculated in the model assuming a first-order loss of $\mathrm{SO}_{2}$ or oxidant (depending on which is the rate limiting step) via uptake by the aerosol (Eq. 1).

$P_{\text {het }}=k\left[\mathrm{SO}_{2}\right.$ or oxidant $]$

The first-order loss rate constant $\left(k, \mathrm{~s}^{-1}\right)$ is calculated using the reaction probability formulation in Jacob (2000) (Eq. 2).

$k=\left(\frac{r_{\mathrm{a}}}{D_{\mathrm{g}}}+\frac{4}{v \gamma}\right)^{-1} A$,

where $r_{\mathrm{a}}$ is the radius of the specific type of aerosol $(\mathrm{cm}), A$ is the total aerosol surface area per unit volume of air for the specific type of aerosol $\left(\mathrm{cm}^{2} \mathrm{~cm}^{-3}\right), v$ is the mean molecular speed of $\mathrm{SO}_{2}$ or the oxidant $\left(\mathrm{cm} \mathrm{s}^{-1}\right), D_{\mathrm{g}}$ represents the gasphase molecular diffusion coefficient of $\mathrm{SO}_{2}$ or the oxidant $\left(\mathrm{cm}^{2} \mathrm{~s}^{-1}\right)$ calculated as follows: 
Table 2. Aqueous-phase reaction rate expressions, rate constants $(k)$, and the influence of ionic strength $\left(I_{\mathrm{S}}\right)$ on the first-order aqueous-phase sulfate production in aerosol.

\begin{tabular}{|c|c|c|c|}
\hline Oxidants & $k\left(\mathrm{~s}^{-1}\right)$ & Uptake gas & References \\
\hline $\mathrm{O}_{3}$ & $\begin{array}{l}k_{1}\left[\mathrm{H}_{2} \mathrm{SO}_{3}\right]+k_{2}\left[\mathrm{HSO}_{3}^{-}\right]+k_{3}\left[\mathrm{SO}_{3}^{2-}\right] \\
k_{1}=2.4 \times 10^{4} \mathrm{M}^{-1} \mathrm{~s}^{-1} \\
k_{2}=3.7 \times 10^{5} \times \exp (-5530 \times(1 / T-1 / 298)) \mathrm{M}^{-1} \mathrm{~s}^{-1} \\
k_{3}=1.5 \times 10^{9} \times \exp (-5280 \times(1 / T-1 / 298)) \mathrm{M}^{-1} \mathrm{~s}^{-1}\end{array}$ & $\mathrm{O}_{3}$ & $\begin{array}{l}\text { Hoffmann and Calvert } \\
\text { (1985) }\end{array}$ \\
\hline $\mathrm{H}_{2} \mathrm{O}_{2}$ & $\begin{array}{l}k_{4}\left[\mathrm{H}^{+}\right]\left[\mathrm{HSO}_{3}^{-}\right] /\left(1+K\left[\mathrm{H}^{+}\right]\right) \\
k_{4}=7.45 \times 10^{7} \times \exp (-4430 \times(1 / T-1 / 298)) \mathrm{M}^{-1} \mathrm{~s}^{-1} \\
K=13 \mathrm{M}^{-1}\end{array}$ & $\mathrm{H}_{2} \mathrm{O}_{2}$ & $\begin{array}{l}\text { McArdle and } \\
\text { Hoffmann (1983) }\end{array}$ \\
\hline $\mathrm{NO}_{2}$ & $\begin{array}{l}k_{5}[\mathrm{~S}(\mathrm{IV})] \\
k_{5 \text { low }}=2 \times 10^{6} \mathrm{M}^{-1} \mathrm{~s}^{-1} \\
k_{5 \text { high }}=(1.24-2.95) \times 10^{7} \mathrm{M}^{-1} \mathrm{~s}^{-1}\end{array}$ & $\mathrm{NO}_{2}$ & $\begin{array}{l}\text { Seinfeld and Pandis } \\
\text { (2012), } \\
\text { Lee and Schwartz } \\
\text { (1983), } \\
\text { Clifton et al. } \\
\text { (1988) }\end{array}$ \\
\hline $\mathrm{TMI}+\mathrm{O}_{2}$ & $\begin{array}{l}k_{6}\left[\mathrm{H}^{+}\right]^{-0.74}[\mathrm{Mn}(\mathrm{II})][\mathrm{Fe}(\mathrm{III})](\mathrm{pH} \leq 4.2) \\
k_{6}=3.72 \times 10^{7} \times \exp (-8431.6 \times(1 / T-1 / 297)) \mathrm{M}^{-2} \mathrm{~s}^{-1} \\
k_{7}\left[\mathrm{H}^{+}\right]^{0.67}[\mathrm{Mn}(\mathrm{II})][\mathrm{Fe}(\mathrm{III})](\mathrm{pH}>4.2) \\
k_{7}=2.51 \times 10^{13} \times \exp (-8431.6 \times(1 / T-1 / 297)) \mathrm{M}^{-2} \mathrm{~s}^{-1} \\
\log \left(\frac{k}{k^{I_{\mathrm{s}}=0}}\right)=b_{1} \sqrt{I_{\mathrm{s}}} /\left(1+\sqrt{I_{\mathrm{s}}}\right) \\
I_{\mathrm{s}, \max }=2 \mathrm{M} \\
b_{1} \text { is in range of }-4 \text { to }-2\end{array}$ & $\mathrm{SO}_{2}$ & $\begin{array}{l}\text { Ibusuki and Takeuchi } \\
\text { (1987) } \\
\text { Martin et al. (1991), } \\
\text { Martin and Hill (1967) }\end{array}$ \\
\hline $\mathrm{HOBr}$ & $\begin{array}{l}k_{8}\left[\mathrm{HSO}_{3}^{-}\right]+k_{9}\left[\mathrm{SO}_{3}^{2-}\right] \\
k_{8}=3.2 \times 10^{9} \mathrm{M}^{-1} \mathrm{~s}^{-1} \\
k_{9}=5.0 \times 10^{9} \mathrm{M}^{-1} \mathrm{~s}^{-1}\end{array}$ & $\mathrm{HOBr}$ & Chen et al. (2017) \\
\hline $\begin{array}{l}\mathrm{O}_{2} \text { on acidic } \\
\text { microdroplet }\end{array}$ & $1.5 \times 10^{6}(\mathrm{pH} \leq 3)$ & $\mathrm{SO}_{2}$ & $\begin{array}{l}\text { Hung and Hoffmann } \\
\text { (2015) }\end{array}$ \\
\hline
\end{tabular}

$$
D_{\mathrm{g}}=\frac{9.45 \times 10^{17} \times \sqrt{T \times\left(3.47 \times 10^{-2}+(1 / M)\right)}}{\rho_{\text {air }}},
$$

where $T$ is air temperature $(\mathrm{K}), \rho_{\text {air }}$ is air density (molecule $\mathrm{m}^{-3}$ ), and $M$ represents the molar mass of $\mathrm{SO}_{2}$ or the oxidant $\left(\mathrm{g} \mathrm{mol}^{-1}\right)$. The reaction probability $(\gamma)$ is defined as the probability that a molecule impacting the aerosol surface undergoes a chemical reaction (Ravishankara, 1997; Jacob, 2000). Due to limited understanding of sulfate formation on aerosols, chemical transport models typically calculate heterogeneous sulfate production rate on aerosols by assuming the bulk first-order uptake of $\mathrm{SO}_{2}$ and using a wide range of $\gamma$ values $\left(10^{-4}-10^{-1}\right)$ (Wang et al., 2014; Zhang et al., 2015). However, the relative contribution of different sulfate production mechanisms, which is important to inform air pollution mitigation efforts, cannot be determined with this simplified approach.

In this study, we use a more specific approach to calculate $\gamma$ for each heterogeneous sulfate production mechanisms following Jacob (2000) and Ammann et al. (2013) (Eq. 4). $\gamma=\left[\frac{1}{\alpha}+\frac{v}{4 K^{*} R T \sqrt{D_{\mathrm{a}} k_{\mathrm{chem}}}} \cdot \frac{1}{f_{\mathrm{r}}}\right]^{-1}$,

where $\alpha$ is the mass accommodation coefficient (unitless), $k_{\text {chem }}$ is the pseudo first-order aqueous-phase chemical rate constant between $\mathrm{S}(\mathrm{IV})$ and the oxidant $\left(\mathrm{O}_{3}\right.$, $\mathrm{H}_{2} \mathrm{O}_{2}, \mathrm{NO}_{2}$ or $\mathrm{O}_{2}$ ) $\left(\mathrm{s}^{-1}\right.$ ) (Table 2), $D_{\mathrm{a}}$ is the aqueousphase molecular diffusion coefficient of $\mathrm{SO}_{2}$ or the oxidant $\left(\mathrm{cm}^{2} \mathrm{~s}^{-1}\right), K^{*}$ is the effective Henry's law constant of $\mathrm{SO}_{2}$ or the oxidant $\left(\mathrm{M} \mathrm{atm}^{-1}\right), R$ is the universal gas constant $\left(\mathrm{L}\right.$ atm $\mathrm{mol}^{-1} \mathrm{~K}^{-1}$ ), and $f_{\mathrm{r}}$ is reacto-diffusive correction term that compares the radius of aerosols $\left(r_{\mathrm{a}}\right)$ with the reactodiffusive length scale of the reaction $(l)$ :

$$
\begin{aligned}
& f_{\mathrm{r}}=\operatorname{coth} \frac{r_{\mathrm{a}}}{l}-\frac{l}{r_{\mathrm{a}}} \\
& l=\sqrt{\frac{D_{\mathrm{a}}}{k_{\text {chem }}}} .
\end{aligned}
$$

In the model, the heterogeneous sulfate production rate from the TMI-catalyzed reaction is calculated as first-order uptake 
in $\mathrm{SO}_{2}$. All other heterogeneous sulfate production pathways are calculated as first-order uptake in the oxidant $\left(\mathrm{H}_{2} \mathrm{O}_{2}, \mathrm{O}_{3}\right.$, and $\mathrm{NO}_{2}$ ). This is based on whether the heterogeneous sulfate production on aerosol is limited by the availability of $\mathrm{SO}_{2}$ or the oxidant. For aerosol $\mathrm{pH}$ values less than 6 , heterogeneous sulfate production rates calculated as a first-order loss in $\mathrm{SO}_{2}$ or the oxidant are similar (Fig. S1b in the Supplement). For aerosol $\mathrm{pH}$ values greater than 6 , heterogeneous sulfate production rates calculated as a first-order loss in $\mathrm{SO}_{2}$ are higher than those calculated as a first-order loss in the oxidants $\mathrm{O}_{3}$ and $\mathrm{NO}_{2}$. The reaction rate for $\mathrm{S}(\mathrm{IV})$ oxidation by $\mathrm{O}_{3}$ and $\mathrm{NO}_{2}$ increases with increasing $\mathrm{pH}$, and at high $\mathrm{pH}$ values $\gamma$ is limited by the mass accommodation coefficient and becomes independent of $\mathrm{pH}$. The mass accommodation coefficients for $\mathrm{O}_{3}\left(2 \times 10^{-3}\right)$ and $\mathrm{NO}_{2}\left(2 \times 10^{-4}\right)$ are much lower than for $\mathrm{SO}_{2}(0.23)$. The mass accommodation coefficient for $\mathrm{H}_{2} \mathrm{O}_{2}(0.11)$ is similar to $\mathrm{SO}_{2}$, and $\gamma$ for the reaction of $\mathrm{S}(\mathrm{IV})$ with $\mathrm{H}_{2} \mathrm{O}_{2}$ was limited by the oxidant concentration. More details on first-order loss rates are described in Text $\mathrm{S} 2$.

In addition to the model simulations described in Table 1, we have also examined heterogeneous oxidation of $\mathrm{SO}_{2}$ by $\mathrm{O}_{2}$ on the surface of acidic microdroplets (Hung and Hoffman, 2015) and by HOBr (Q. Chen et al., 2016; 2017). The results are described in Text $\mathrm{S} 2$.

\subsection{Observations of sulfate concentrations and oxygen isotopic composition}

Between 17 October 2014 and 20 January 2015, $\mathrm{PM}_{2.5}$ samples were collected every $12 \mathrm{~h}$ for daytime (08:00-20:00 Beijing time) and nighttime (20:00-08:00 Beijing time) conditions at the campus of the University of the Chinese Academy of Sciences $\left(40.41^{\circ} \mathrm{N}, 116.68^{\circ} \mathrm{E}, 20 \mathrm{~m}\right.$ from the ground) in Beijing, around $60 \mathrm{~km}$ northeast of downtown. The oxygen-17 excess of sulfate $\left(\Delta^{17} \mathrm{O}\left(\mathrm{SO}_{4}^{2-}\right)\right)$ of these $\mathrm{PM}_{2.5}$ samples were measured at University of Washington, Seattle. A detailed description of sampling and measurements of $\Delta^{17} \mathrm{O}\left(\mathrm{SO}_{4}^{2-}\right)$ can be found in He et al. (2018). Observations of hourly sulfate concentrations were conducted at the Institute of Atmospheric Physics (IAP), Chinese Academy of Sciences $\left(39.99^{\circ} \mathrm{N}, 116.37^{\circ} \mathrm{E}\right)$, an urban site in the north of Beijing, at ground level $(\sim 4 \mathrm{~m})$, as described by Sun et al. (2016). Sulfate concentrations in submicron aerosols $\left(\mathrm{PM}_{1}\right)$ were measured by an Aerodyne High Resolution Aerosol Mass Spectrometer (HR-AMS). The difference of $\mathrm{SO}_{4}^{2-}$ concentration between $\mathrm{PM}_{2.5}$ and $\mathrm{PM}_{1}$ is small because most sulfates exist in fine aerosols (Guo et al., 2014). A comparison of $\mathrm{SO}_{4}^{2-}$ concentration in $\mathrm{PM}_{2.5}$ and $\mathrm{PM}_{1}$ during 22-29 November 2017 is shown in the Supplement (Fig. S2). Surface $\mathrm{PM}_{2.5}, \mathrm{SO}_{2}, \mathrm{NO}_{2}$, and $\mathrm{O}_{3}$ measurements (Figs. 1 and S6) are from the China National Environmental Monitoring Center (http://106.37.208.233:20035/, last access: 1 May 2019) with 12 sites in Beijing, including 8 urban and 4 suburban sites.

\section{Results}

\subsection{Observed $\mathrm{PM}_{2.5}$ and sulfate concentrations and $\Delta^{17} \mathbf{O}\left(\mathrm{SO}_{4}^{2-}\right)$}

Figure 1 shows the time series of observed concentrations of $\mathrm{PM}_{2.5}$ and sulfate from 17 October 2014 to 20 January 2015, along with temperature and relative humidity in Beijing from GEOS-FP. A previous study showed that the GEOS-FP meteorological data for temperature and relative humidity are in good agreement with the ground-based measurements in Beijing $\left(R^{2}>0.9\right)$ (Zhang et al., 2016). The CNAAQS defines the $24 \mathrm{~h}$ average air quality levels as excellent $\left(\mathrm{PM}_{2.5}=0-35 \mu \mathrm{g} \mathrm{m}^{-3}\right)$, good $\left(\mathrm{PM}_{2.5}=35-75 \mu \mathrm{g} \mathrm{m}^{-3}\right)$, light $\left(\mathrm{PM}_{2.5}=75-115 \mu \mathrm{g} \mathrm{m}^{-3}\right)$, moderate $\left(\mathrm{PM}_{2.5}=115-\right.$ $\left.150 \mu \mathrm{g} \mathrm{m}^{-3}\right)$, heavy $\left(\mathrm{PM}_{2.5}=150-250 \mu \mathrm{g} \mathrm{m}^{-3}\right)$, and severe $\left(\mathrm{PM}_{2.5}>250 \mu \mathrm{g} \mathrm{m}^{-3}\right)$. Using this metric, 10 time periods are categorized as heavy or severe ( $\left.>150 \mathrm{\mu g} \mathrm{m}^{-3}\right)$ during 17 October 2014-20 January 2015, and we refer to these as "heavy polluted period" (HPP). Another 10 time periods were in the excellent to good category and we refer to these days as "clean period" $(\mathrm{CP})$. The average relative humidity $(\mathrm{RH})$ from GEOS-FP during HPP was $60 \pm 11 \%$, much higher than the average RH during CP $(42 \pm 10 \%)$. Higher RH can accelerate the rates of conversion of $\mathrm{SO}_{2}$ and $\mathrm{NO}_{2}$ to $\mathrm{SO}_{4}^{2-}$ and $\mathrm{NO}_{3}^{-}$, respectively, contributing to increases in $\mathrm{PM}_{2.5}$ concentrations (Wang et al., 2016; Hua et al., 2015).

The observed $\mathrm{SO}_{4}^{2-}$ concentrations show a similar variation as $\mathrm{PM}_{2.5}$, increasing from $2.1 \pm 1.8 \mu \mathrm{g} \mathrm{m}^{-3}$ in $\mathrm{CP}$ to $25.9 \pm 11.3 \mu \mathrm{g} \mathrm{m}^{-3}$ in HPP with a mean of $11.5 \pm 7.3 \mu \mathrm{g} \mathrm{m}^{-3}$ during the entire measurement period. The mass fraction of $\mathrm{SO}_{4}^{2-}$ to $\mathrm{PM}_{2.5}$ ranged from $5 \%$ to $19 \%$, varying from a mean of $8 \pm 2 \%$ in CP to $13 \pm 2 \%$ in HPP. Observed sulfate concentrations shown in Fig. 1 are $15 \%$ lower on average during HPP than those reported in He et al. (2018) because the $\mathrm{SO}_{4}^{2-}$ concentrations shown here represent $\mathrm{PM}_{1}$ instead of $\mathrm{PM}_{2.5}$, which is in good agreement with previous studies (Sun et al., 2013, 2014, 2016) (Fig. S2). Figure 1 also shows the observed sulfur oxidation ratio (SOR), defined as the molar ratio of sulfate over the sum of sulfate and $\mathrm{SO}_{2}\left(\mathrm{SO}_{4}^{2-} /\left(\mathrm{SO}_{2}+\mathrm{SO}_{4}^{2-}\right)\right)($ Colbeck and Harrison, 1984). The observed SOR increases from CP $(9 \pm 6 \%)$ to HPP $(32 \pm 18 \%)$, consistent with increased sulfate production rates during HPP.

Figures 2 and $\mathrm{S} 4$ show the $\Delta^{17} \mathrm{O}\left(\mathrm{SO}_{4}^{2-}\right)$ observations, 24 measurements represent HPP and 10 represent CP. The $\Delta^{17} \mathrm{O}\left(\mathrm{SO}_{4}^{2-}\right)$ values are similar in HPP and $\mathrm{CP}, 0.9 \pm$ $0.1 \%$ and $0.9 \pm 0.5 \%$, respectively. A more detailed description of the $\Delta^{17} \mathrm{O}\left(\mathrm{SO}_{4}^{2-}\right)$ observations can be found in $\mathrm{He}$ et al. (2018). 
(a) Temp

$(\mathrm{K})$

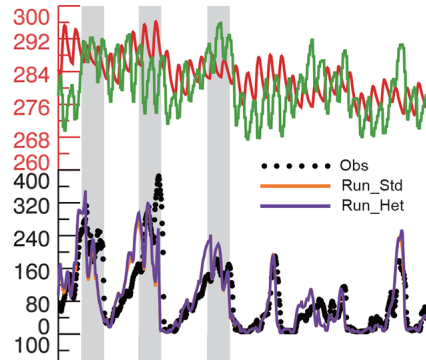

(b) $\mathbf{P M}_{2.5}$

( $\mu \mathrm{g} \mathrm{m}^{-3}$ )

(c) $\mathrm{SO}_{4}^{2-}$
$\left(\mu \mathrm{g} \mathrm{m}^{-3}\right)$

$\mathrm{SO}_{4}^{2-}$
$\left(\mu \mathrm{g} \mathrm{m}^{-3}\right)$

(d) SOR

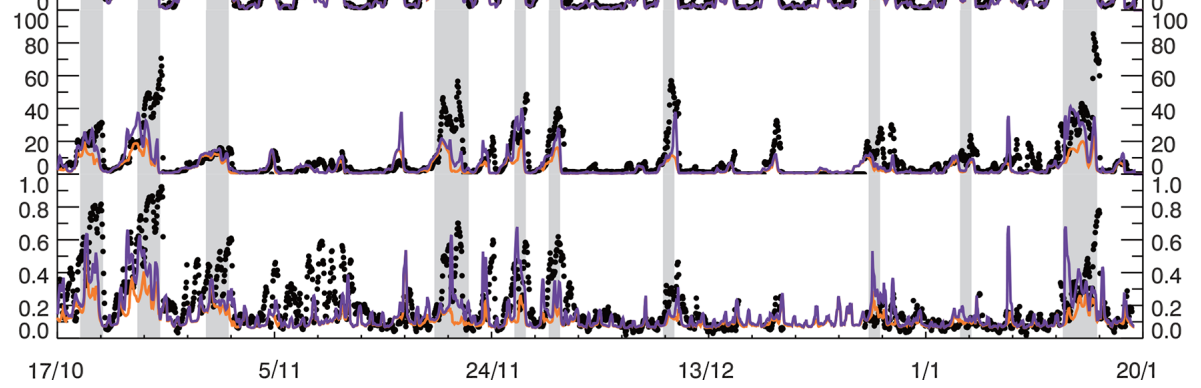

Figure 1. Time series of (a) GEOS-FP temperature (red line) and relative humidity (RH; green line), (b) $\mathrm{PM}_{2.5}$ and (c) sulfate concentration, and (d) SOR at the surface in Beijing during the study period of 17 October 2014-20 January 2015. Hourly PM 2.5 , sulfate, and SOR observations (black dots) are compared with model results from Run_Std (orange line) and Run_Het (purple line). The gray-shaded bars represent 10 heavy pollution periods (HPPs) $\left(\mathrm{PM}_{2.5}>150 \mu \mathrm{g} \mathrm{m}^{-3}\right)$ as defined in the text.

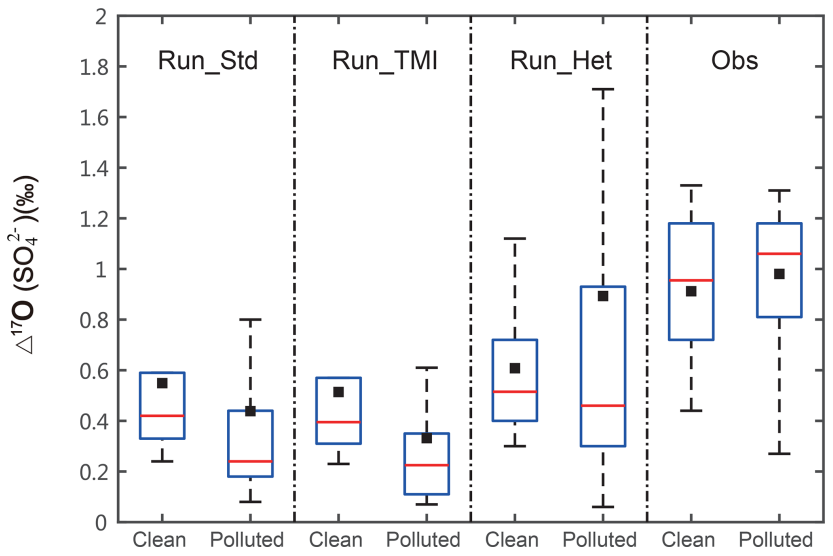

Figure 2. The box charts show observed vs. modeled $\Delta^{17} \mathrm{O}\left(\mathrm{SO}_{4}^{2-}\right)$ in Beijing for each model simulation, separated for heavy pollution and clean periods. The box line from bottom to top is, respectively, the percentile of $25 \%, 50 \%$, and $75 \%$; the whisker from bottom to top is, respectively, the minimum and the maximum; and the black square is mean value.

\subsection{Analyses of sulfate formation pathways}

\subsubsection{Sulfate formation in the standard model}

Figure 1 compares the measured and modeled $\mathrm{PM}_{2.5}$ and sulfate concentration in Beijing. The standard model (Run_Std) generally captures the temporal variations in $\mathrm{PM}_{2.5}$ and $\mathrm{SO}_{4}^{2-}$ observations during the entire sampling period but underestimates the $\mathrm{PM}_{2.5}$ and $\mathrm{SO}_{4}^{2-}$ observations during HPP by $28 \%$ and $64 \%$, respectively. Modeled sulfate con- centrations increase from $1.5 \pm 1.2 \mu \mathrm{g} \mathrm{m}^{-3}$ in $\mathrm{CP}$ to $8.9 \pm$ $3.1 \mu \mathrm{g} \mathrm{m}^{-3}$ in HPP, which is a much smaller enhancement compared to observations (from $2.1 \pm 1.8 \mu \mathrm{g} \mathrm{m}^{-3}$ in $\mathrm{CP}$ to $25.9 \pm 11.3 \mu \mathrm{g} \mathrm{m}^{-3}$ in HPP). The model-simulated sulfate mass fractions in $\mathrm{PM}_{2.5}$ are $8 \pm 2 \%$ in CP and $7 \pm 2 \%$ in HPP. The model fails to reproduce increases in observed sulfate mass fraction from CP $(8 \pm 2 \%)$ to HPP $(13 \pm 2 \%)$. This is consistent with previous modeling studies, suggesting missing sulfate formation pathways (Wang et al., 2014; Zhang et al., 2015). The model also underestimates the sulfur oxidation ratio (SOR) observations during HPP by $53 \%$. This further suggests that the modeled $\mathrm{SO}_{2}$ oxidation rate is too slow.

Figure 2 compares observed and modeled $\Delta^{17} \mathrm{O}\left(\mathrm{SO}_{4}^{2-}\right)$. The modeled hourly $\Delta^{17} \mathrm{O}\left(\mathrm{SO}_{4}^{2-}\right)$ values were averaged at $12 \mathrm{~h}$ intervals for comparison with the observations. The simulated $\Delta^{17} \mathrm{O}\left(\mathrm{SO}_{4}^{2-}\right)$ values in Run_Std range from $0.02 \%$ to $1.5 \%$ with a mean of $0.5 \pm 0.1 \%$. Unlike the observations, modeled $\Delta^{17} \mathrm{O}\left(\mathrm{SO}_{4}^{2-}\right)$ values in Run_Std during HPP $(0.4 \pm$ $0.1 \%$ ) are lower than those during $\mathrm{CP}(0.6 \pm 0.1 \%$ ) due to higher fractional contribution of in-cloud $\mathrm{H}_{2} \mathrm{O}_{2}$ and $\mathrm{O}_{3}$ oxidation pathways during $\mathrm{CP}$, as discussed below. Run_Std underestimates the $\Delta^{17} \mathrm{O}\left(\mathrm{SO}_{4}^{2-}\right)$ observations (by $44 \%$ on average), particularly during HPP (by $53 \%$ on average).

Figure 3 shows modeled spatial distribution of sulfate concentrations over China, and the fractional contribution of each sulfate formation pathway to total sulfate abundance in Beijing. The average simulated sulfate concentration in Beijing in Run_Std is around $6.2 \mu \mathrm{g} \mathrm{m}^{-3}$ (Fig. 3a), smaller than the observations $\left(11.5 \mu \mathrm{g} \mathrm{m}^{-3}\right)$ over the study period. Figure 3 also shows the model calculated average contri- 
(a) Run_SD

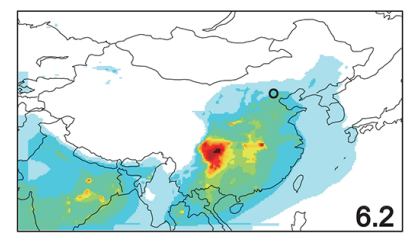

(b) Run_TMI

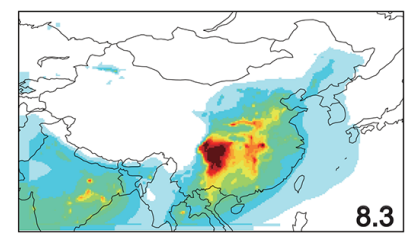

(c) Run_Het

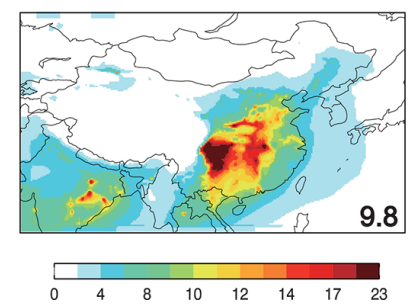

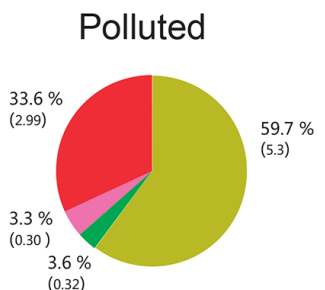
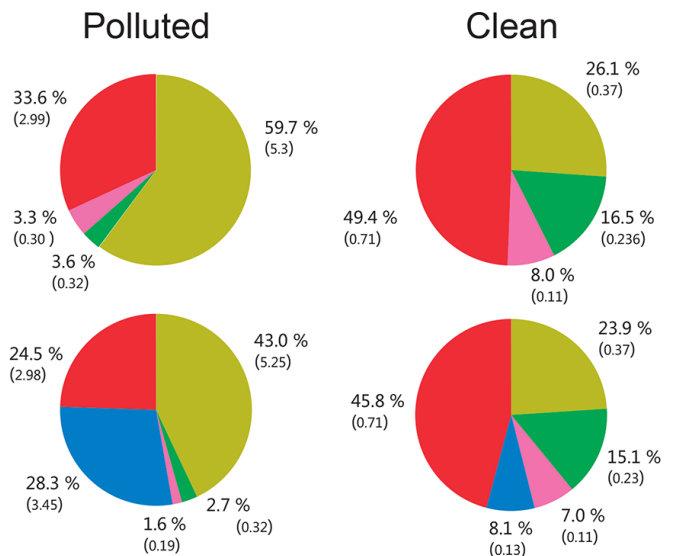

- Gas_OH

- Cloud_ $\mathrm{H}_{2} \mathrm{O}_{2}$

- Cloud_O ${ }_{3}$

-Cloud_TMI

Primary sulfate

- Heterogeneous sulfate

Het_O

- $\mathrm{Het} \_\mathrm{H}_{2} \mathrm{O}_{2}$

Het_NO

Het_TMI
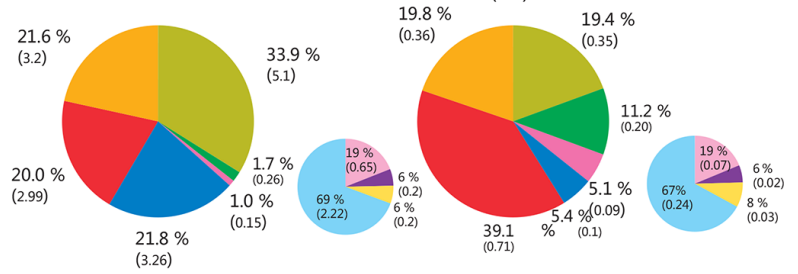

Figure 3. Model-simulated sulfate aerosol concentrations $\left(\mu \mathrm{g} \mathrm{m}^{-3}\right)$ above the ground for (a) Run_Std, (b) Run_TMI, and (c) Run_Het. Panels on the left show the spatial distributions with the numbers in the inset representing simulated mean sulfate concentrations in Beijing (black circle in a) during the entire measurement period. The middle and right columns show the percent contributions of different sulfate formation pathways to sulfate aerosol concentration in Beijing as calculated by the different model runs during polluted (HPP) and clean (CP) periods, respectively. The smaller pie charts in (c) show the relative contributions of the four heterogeneous sulfate formation pathways implemented in the model. Numbers are percentage contributions $(\%)$ and the absolute sulfate concentrations $\left(\mu \mathrm{g} \mathrm{m}^{-3}\right)$ are in parentheses.

bution of each sulfate production pathway to total sulfate concentration at the surface in Beijing during HPP and CP. In Run_Std, sulfate produced by gas-phase oxidation of $\mathrm{SO}_{2}$ by $\mathrm{OH}$ dominates the total sulfate abundance $(59.7 \%$, $5.3 \mu \mathrm{g} \mathrm{m}^{-3}$ ) in HPP. Primary sulfate represents the second most important contributor $\left(33.6 \%, 3.0 \mu \mathrm{g} \mathrm{m}^{-3}\right)$ despite the fact that primary sulfate is only $3 \%$ of total anthropogenic sulfur emissions. The high fraction of primary anthropogenic sulfate reflects the relatively slow oxidation rate of $\mathrm{SO}_{2}$ in the model. In-cloud sulfate production contributes only $7 \%$ of total sulfate abundance at the surface during HPP. For clean days, primary sulfate dominates surface sulfate concentrations $\left(49.4 \%, 0.7 \mu \mathrm{g} \mathrm{m}^{-3}\right)$, suggesting an even slower $\mathrm{SO}_{2}$ oxidation rate in the model during CP compared to HPP. Gasphase production via $\mathrm{OH}$ oxidation is the second most important contributor $\left(26.1 \%, 0.4 \mu \mathrm{g} \mathrm{m}^{-3}\right)$ during CP. Gas-phase oxidation of $\mathrm{SO}_{2}$ by $\mathrm{OH}$ is more important in HPP than in CP because modeled $\mathrm{OH}$ concentrations during HPP are much higher than in $\mathrm{CP}$, consistent with observations of high $\mathrm{OH}$ during polluted wintertime conditions in Beijing (Tan et al., 2018). Higher modeled OH in HPP compared to CP is due to higher nitrous acid (HONO) levels during HPP (Fig. S3) resulting from heterogeneous uptake of $\mathrm{NO}_{2}$ to produce $\mathrm{HNO}_{3}$ and HONO in the model. This is consistent with observationbased studies in Beijing showing that $\mathrm{OH}$ production from $\mathrm{HONO}$ photolysis is 10 times higher than that from $\mathrm{O}_{3}$ pho- tolysis in winter (Hendrick et al., 2014) and that $\mathrm{NO}_{2}$ (g) dissolution in acidic aerosol water is a source of HONO ( $\mathrm{Li}$ et al., 2018). In-cloud sulfate production contributes $24.5 \%$ of total sulfate abundance during $\mathrm{CP}$, much higher than HPP (6.9\%) due to higher modeled $\mathrm{H}_{2} \mathrm{O}_{2}$ and $\mathrm{O}_{3}$ in $\mathrm{CP}$.

\subsubsection{Transition metal ion-catalyzed oxidation of S(IV) in clouds}

The in-cloud concentration of soluble $\mathrm{Fe}^{3+}$ and $\mathrm{Mn}^{2+}$ determines the rate of sulfate formation via the TMI-catalyzed oxidation pathway, but large uncertainties exist in estimates of soluble $\mathrm{Fe}^{3+}$ and $\mathrm{Mn}^{2+}$ due to lack of observations. Adding aqueous-phase TMI-catalyzed $\mathrm{S}(\mathrm{IV})$ oxidation by $\mathrm{O}_{2}$ in cloud droplets in Run_TMI increases the average sulfate concentration in Beijing during the entire measurement period from 6.2 to $8.3 \mu \mathrm{g} \mathrm{m}^{-3}$ due to increases in the in-cloud sulfate production rate. However, the model still underestimates observations of $\mathrm{PM}_{2.5}(-35 \%)$, sulfate $(-48 \%)$, and SOR $(-40 \%)$ during HPP. Sulfate from TMI-catalyzed oxidation dominates in-cloud sulfate production and accounts for up to $28.3 \%$ of total sulfate abundance during HPP but only $8.1 \%$ during $\mathrm{CP}$ in Beijing (Fig. 3b). The lower contribution of TMI catalysis during CP is due to lower concentrations of $\mathrm{Fe}$ and $\mathrm{Mn}$ in the model during $\mathrm{CP}$. The largest enhancement in sulfate abundance after adding the in-cloud TMI pathway occurs in the Sichuan basin (around $6.5 \mu \mathrm{g} \mathrm{m}^{-3}$ ), where sim- 
ulated anthropogenic Fe and Mn from coal fly ash (Fig. S4) and $\mathrm{SO}_{2}$ are high due to high $\mathrm{SO}_{2}$ emissions (Zhang et al., 2009) combined with stagnant air and high relative humidity all year (Huang et al., 2014). After adding the in-cloud TMI oxidation pathway, the average modeled $\Delta^{17} \mathrm{O}\left(\mathrm{SO}_{4}^{2-}\right)$ decreased from $0.5 \%$ to $0.4 \%$ in Beijing because the TMI oxidation pathway leads to $\Delta^{17} \mathrm{O}\left(\mathrm{SO}_{4}^{2-}\right)=0 \%$ (Fig. 2), which makes the discrepancy between modeled and observed $\Delta^{17} \mathrm{O}\left(\mathrm{SO}_{4}^{2-}\right)(0.9 \%)$ even larger.

\subsubsection{Heterogeneous sulfate formation on aerosols}

Adding four heterogeneous S(IV) oxidation mechanisms by $\mathrm{H}_{2} \mathrm{O}_{2}, \mathrm{O}_{3}, \mathrm{NO}_{2}$ and TMI-catalyzed $\mathrm{O}_{2}$ on aerosols in Run_Het increases the average $\mathrm{SO}_{4}^{2-}$ concentrations in Beijing (from $8.3 \mu \mathrm{g} \mathrm{m}^{-3}$ in Run_Std to $9.8 \mu \mathrm{g} \mathrm{m}^{-3}$ in Run_Het) (Fig. 1c). Modeled heterogeneous sulfate production represents $21.6 \%$ of total surface sulfate concentrations in HPP and $19.8 \%$ in CP (Fig. 3c). Modeled daily mean aerosol pH ranged from 3.0 to 5.4 with a mean of 4.3 over the entire time period in Beijing (Fig. 4), which is consistent with recent estimates ( $\mathrm{pH}=4.2-4.7)$ (Guo et al., 2017; Song et al., 2018; Liu et al., 2017). Heterogeneous sulfate production on aerosols is dominated by TMI-catalyzed $\mathrm{O}_{2}$ oxidation in both HPP $(69 \%)$ and CP (67\%) (Fig. 3c). S(IV) oxidation by $\mathrm{O}_{3}$ is the second most important heterogeneous oxidation pathway, accounting for $19 \%$ of total heterogeneous sulfate formation in both HPP and CP. S(IV) oxidation by $\mathrm{H}_{2} \mathrm{O}_{2}(6 \%$ in both HPP and CP) and $\mathrm{NO}_{2}(6 \%$ in HPP and $8 \%$ in CP) represent a minor heterogeneous sulfate production pathway. Previous studies suggested that oxidation of $\mathrm{SO}_{2}$ by $\mathrm{NO}_{2}$ in aerosol water dominates heterogeneous sulfate formation in Beijing during winter (Wang et al., 2016; Cheng et al., 2016) at neutral aerosol $\mathrm{pH}$. However, subsequent studies showed that these high aerosol $\mathrm{pH}$ values were unlikely during wintertime Beijing haze events and they calculated aerosol $\mathrm{pH}$ values in the range of 4.2-4.7 (Guo et al., 2017; Song et al., 2018; Liu et al., 2017).

After adding the heterogeneous S(IV) oxidation pathways, the average modeled $\Delta^{17} \mathrm{O}\left(\mathrm{SO}_{4}^{2-}\right)$ increased from $0.5 \pm 0.5 \%$ o to $0.8 \pm 0.7 \%$ in Beijing, due to the increased importance of $\mathrm{S}(\mathrm{IV})$ oxidation by $\mathrm{O}_{3}$. Although the average modeled $\Delta^{17} \mathrm{O}\left(\mathrm{SO}_{4}^{2-}\right)$ in Run_Het is similar to the observations $(0.9 \pm 0.3 \%$ o $)$, the modeled median $(0.5 \%$ ) largely underestimates the observed median (1.0\%o) (Fig. 2), and the majority of the modeled data underestimate the observed $\Delta^{17} \mathrm{O}\left(\mathrm{SO}_{4}^{2-}\right)$ (Fig. S5).

Compared to observations in Beijing, mean model biases decrease from $-28 \%$ to $-26 \%$ for $\mathrm{PM}_{2.5},-45 \%$ to $-21 \%$ for sulfate concentration, from $-29 \%$ to $-11 \%$ for SOR, and from $-45 \%$ to $-15 \%$ for $\Delta^{17} \mathrm{O}\left(\mathrm{SO}_{4}^{2-}\right)$ for the entire measurement period for Run_Het relative to Run_Std. Model biases during HPP decrease from $-38 \%$ to $-32 \%$ for $\mathrm{PM}_{2.5},-65 \%$ to $-40 \%$ for sulfate concentration, $-53 \%$ to $-28 \%$ for SOR, and from $-50 \%$ to $-5 \%$ for $\Delta^{17} \mathrm{O}\left(\mathrm{SO}_{4}^{2-}\right)$.
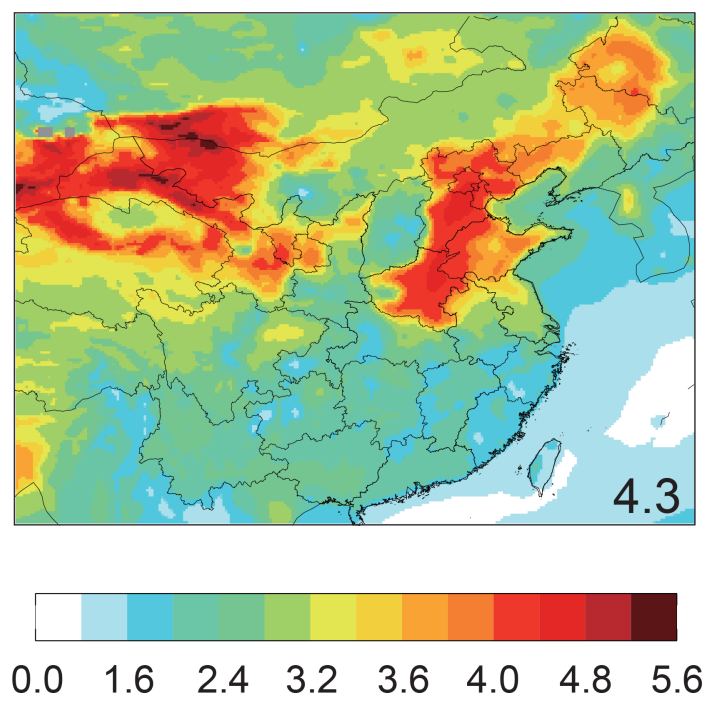

Figure 4. Model-simulated mean aerosol $\mathrm{pH}$ values at the surface in China from 17 October 2014 to 20 January 2015 from Run_Het. Number in inset represents the mean calculated $\mathrm{pH}$ values in Beijing.

The largest sulfate enhancements due to heterogeneous sulfate formation occur in megacities in eastern China and the Sichuan basin (Fig. 3), where both $\mathrm{SO}_{2}$ and aerosol abundances are highest. In addition, high anthropogenic emissions of $\mathrm{Fe}^{3+}$ and $\mathrm{Mg}^{2+}$ favor sulfate production catalyzed by TMIs. In Run_Het, the fractional contribution of each sulfate production mechanism in Beijing during HPP is $34 \%$ for gas-phase oxidation of $\mathrm{SO}_{2}$ by $\mathrm{OH}, 22 \%$ for TMI catalysis in cloud, $21 \%$ for the four heterogeneous oxidation pathways, and $20 \%$ for primary sulfate, respectively (Fig. 3c). The remaining $3 \%$ of sulfate is formed via in-cloud sulfate production from $\mathrm{H}_{2} \mathrm{O}_{2}$ and $\mathrm{O}_{3}$. For clean days $(\mathrm{CP})$, primary sulfate still dominates surface sulfate concentrations (39\%) in Run_Het, with gas-phase production via $\mathrm{OH}$ oxidation the second most important contributor $(22 \%)$ and the added heterogeneous sulfate formation pathways accounting for $22 \%$.

\section{Discussion}

The model results demonstrate that implementation of heterogeneous sulfate formation pathways on aerosols reduces modeled low biases in both the concentration and oxygen isotopic signature of sulfate $\left(\Delta^{17} \mathrm{O}\left(\mathrm{SO}_{4}^{2-}\right)\right)$ and suggests that TMI catalysis dominates heterogeneous sulfate production. However, the model is still biased low in both metrics, indicating that the model is still underestimating sulfate production rates. The modeled underestimate in $\Delta^{17} \mathrm{O}\left(\mathrm{SO}_{4}^{2-}\right)$ reveals an underestimate in the $\mathrm{O}_{3}$ oxidation pathway. Since the relative contribution of heterogeneous sulfate formation pathways are sensitive to aerosol $\mathrm{pH}$, we investigated the influence of aerosol $\mathrm{pH}$ using a series of sensitivity simu- 
lations with prescribed aerosol $\mathrm{pH}$ values between 2 and 8 (Table 1). Figure 5 shows modeled sulfate concentrations produced from different oxidation pathways and resulting $\Delta^{17} \mathrm{O}\left(\mathrm{SO}_{4}^{2-}\right)$ in Beijing averaged over HPP assuming different aerosol $\mathrm{pH}$ values. Heterogeneous sulfate formation represents over $50 \%$ of total sulfate formation when $\mathrm{pH}>5$ and when $\mathrm{pH}<4$. At aerosol $\mathrm{pH}<4$, heterogeneous sulfate formation is dominated by the TMI pathway because of the high solubility of $\mathrm{Fe}$ and $\mathrm{Mn}$ at low pH (Guieu et al., 1994; Mackie et al., 2005). At aerosol $\mathrm{pH}>5$, heterogeneous sulfate formation is dominated by the $\mathrm{O}_{3}$ pathway because the solubility of $\mathrm{SO}_{2}$ increases with increasing $\mathrm{pH}$ and because the $\mathrm{S}(\mathrm{IV})$ partitioning shifts to favor $\mathrm{SO}_{3}^{2-}$ at higher $\mathrm{pH}$. The aqueous-phase rate constant for $\mathrm{SO}_{3}^{2-}+\mathrm{O}_{3}$ is almost 4 orders of magnitude faster than for $\mathrm{HSO}_{3}^{-}+\mathrm{O}_{3}$ (Table 2). Heterogeneous sulfate formation by $\mathrm{NO}_{2}$ also increases with increasing $\mathrm{pH}$ due to the increased solubility of $\mathrm{SO}_{2}$ at high $\mathrm{pH}$, and represents $15 \%-30 \%$ of total heterogeneous sulfate production between $\mathrm{pH} 6$ and 8 . In contrast to our results, previous results (Cheng et al., 2016; Wang et al., 2016) suggested that $\mathrm{NO}_{2}$ oxidation is more important than $\mathrm{O}_{3}$ oxidation at high $\mathrm{pH}$ values. The difference is due to assumed $\mathrm{O}_{3}$ concentrations used in the rate calculations. The aforementioned studies assumed an $\mathrm{O}_{3}$ concentration of $1 \mathrm{ppb}$ relative to an $\mathrm{NO}_{2}$ concentration of $66 \mathrm{ppb}$. In our model simulations, average $\mathrm{O}_{3}$ and $\mathrm{NO}_{2}$ concentrations are 9 and $85 \mathrm{ppb}$, respectively. Modeled $\mathrm{O}_{3}$ concentrations are similar to the observations during the measurement period (Fig. S6). Heterogeneous sulfate production is lower $(20 \%)$ when $\mathrm{pH} 4-5$ because of the low solubility of $\mathrm{Fe}$ and $\mathrm{Mn}$ and low concentrations of $\mathrm{SO}_{3}^{2-}$ in this $\mathrm{pH}$ range. We note that while the $\mathrm{pH}$-dependence of $\mathrm{S}(\mathrm{IV})$ partitioning is well known, the $\mathrm{pH}$ dependency of metal solubility is more uncertain.

Anthropogenic $\mathrm{SO}_{2}$ emissions in China have been reduced sharply since 2009 due to the stringent pollution control measures implemented (Zheng et al., 2018; Van der A et al., 2017; Krotkov et al., 2016). Compared with 2010, anthropogenic $\mathrm{SO}_{2}$ emissions were reduced by about $50 \%$ in 2015 (Krotkov et al., 2016; Zheng et al., 2018; Van der A et al., 2017). However, $\mathrm{NH}_{3}$ and NMVOC emissions in China remained stable during 2010-2017 due to the absence of effective mitigation measures in current policies (Zheng et al., 2018). The emission changes may affect the abundance of species that influence cloud and aerosol $\mathrm{pH}$ and further influence sulfate production rates and the contribution of each sulfate formation pathway. However, other studies using observations between 2014 and 2016 (Liu et al., 2017; Song et al., 2018) found a similar $\mathrm{pH}$ range to that calculated here, suggesting that a modeled low bias in aerosol $\mathrm{pH}$ is not likely to be the source of the modeled discrepancy in $\Delta^{17} \mathrm{O}\left(\mathrm{SO}_{4}^{2-}\right)$.

Figure 5 also shows that model results with mean aerosol $\mathrm{pH}>5$ would result in a high bias in $\Delta^{17} \mathrm{O}\left(\mathrm{SO}_{4}^{2-}\right)$ due to the increasing importance of the $\mathrm{O}_{3}$ oxidation pathway at higher $\mathrm{pH}$ values, effectively providing an observational constraint

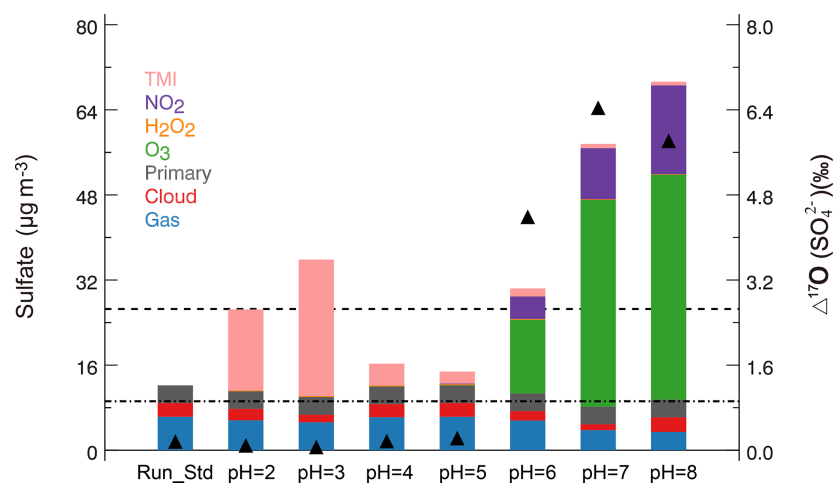

Figure 5. Model-simulated mean sulfate concentration in Beijing averaged over heavy pollution periods (HPP, as defined in the text). Model results are from the standard simulation (Run_Std) and sensitivity simulations with prescribed aerosol $\mathrm{pH}$ ranging from 2 to 8 . Different colors represent contributions from different sulfate formation pathways, including four heterogeneous reactions: oxidation by $\mathrm{O}_{2}$ (TMI), $\mathrm{NO}_{2}, \mathrm{H}_{2} \mathrm{O}_{2}, \mathrm{O}_{3}$; primary anthropogenic, aqueousphase oxidation in clouds; and gas-phase oxidation. Also shown are the corresponding modeled $\Delta^{17} \mathrm{O}\left(\mathrm{SO}_{4}^{2-}\right)$ values in Beijing (black triangles). The dashed line denotes observed mean sulfate concentration $\left(25.9 \mathrm{\mu g} \mathrm{m}^{-3}\right)$, and the dotted, dashed line denotes observed mean $\Delta^{17} \mathrm{O}\left(\mathrm{SO}_{4}^{2-}\right)(0.9 \%$ ) during HPP in Beijing.

for typical aerosol $\mathrm{pH}<5$ in Beijing haze. However, modeled $\Delta^{17} \mathrm{O}\left(\mathrm{SO}_{4}^{2-}\right)$ calculated at the aerosol $\mathrm{pH}$ of 4.2-4.7, as estimated by recent studies (Guo et al., 2017; Song et al., 2018) represents a low bias relative to the observations. A joint comparison of observations and model results with both sulfate concentrations and $\Delta^{17} \mathrm{O}\left(\mathrm{SO}_{4}^{2-}\right)$ suggests an average aerosol $\mathrm{pH}$ between 5 and 6 in Beijing during the study period, which is higher than bulk aerosol $\mathrm{pH}$ calculations in our model calculations and in previous studies (Guo et al., 2017; Song et al., 2018).

Thermodynamic $\mathrm{pH}$ calculations in ISORROPIA II are based on the assumption of internally mixed aerosols and do not directly consider aerosol alkalinity (carbonate). Fresh dust is initially alkaline (calcium carbonates). This alkalinity is partially depleted (carbonate is converted to $\mathrm{CO}_{2}$ ) upon uptake of the acid gases $\mathrm{HNO}_{3}, \mathrm{SO}_{2}$, and $\mathrm{H}_{2} \mathrm{SO}_{4}$ (Fairlie et al., 2010; Usher et al., 2003). Due to the high pH of alkaline dust, uptake of $\mathrm{SO}_{2}$ would be followed by heterogeneous oxidation by $\mathrm{O}_{3}$ (Fairlie et al., 2010; Ullerstam et al., 2003) and $\mathrm{NO}_{2}$ (Zhao et al., 2018) if there is enough aerosol liquid water to promote aqueous-phase oxidation. A recent modeling study by Uno et al. (2017) using a previous version of GEOSChem explicitly includes uptake of $\mathrm{HNO}_{3}, \mathrm{SO}_{2}$, and $\mathrm{H}_{2} \mathrm{SO}_{4}$ on alkaline dust aerosols as described in Fairlie et al. (2010). Their model calculated that sulfate from uptake of $\mathrm{SO}_{2}$ and $\mathrm{H}_{2} \mathrm{SO}_{4}$ on alkaline dust in Beijing during our measurement period represents on average $3 \%$ of total sulfate abundance. Most of this sulfate formation on alkaline dust was from uptake of $\mathrm{H}_{2} \mathrm{SO}_{4}$ (70\%-80\%, Fairlie et al., 2010), with the re- 
maining fraction $(20 \%-30 \%)$ from uptake of $\mathrm{SO}_{2}$, followed by oxidation to sulfate. On average, less than $1 \%$ of sulfate in Beijing is formed on alkaline dust via the uptake and oxidation of $\mathrm{SO}_{2}$ in the model.

At $\mathrm{pH}$ values representative of alkaline dust $(\mathrm{pH}=7-$ 8), sulfate formed via oxidation of $\mathrm{SO}_{2}$ on alkaline dust would be dominated by $\mathrm{O}_{3}$, leading to a relatively high $\Delta^{17} \mathrm{O}\left(\mathrm{SO}_{4}^{2-}\right)$ value of $6 \%$ (Fig. 5). In order to account for the difference in the median $\Delta^{17} \mathrm{O}\left(\mathrm{SO}_{4}^{2-}\right)$ observed $(1.0 \%$ ) and modeled $(0.5 \%)$, sulfate formation from the uptake and oxidation of $\mathrm{SO}_{2}$ on alkaline dust would need to account for an average of $9 \%$ of total sulfate abundance during our measurement period. This fraction is higher than that calculated in Uno et al. (2017), which did not include anthropogenic dust. In our model, anthropogenic dust accounts for $28 \%$ of total dust in Beijing (Fig. S7), and natural dust mostly originates from the Gobi Desert in southwestern Mongolia and the Badain Jaran Desert in northern China (Zhang et al., 2003, 2016). The anthropogenic dust is not abundant enough to explain the difference between the results of Uno et al. (2017) and amount of sulfate production on alkaline dust required to explain the observed $\Delta^{17} \mathrm{O}\left(\mathrm{SO}_{4}^{2-}\right)$. Due to uncertainties in processes such as the $\mathrm{RH}$ dependence of the uptake of $\mathrm{SO}_{2}$ on alkaline dust, the importance of this pathway could be underestimated in Uno et al. (2017). If this process does account for the difference in modeled and observed $\Delta^{17} \mathrm{O}\left(\mathrm{SO}_{4}^{2-}\right)$, then $\mathrm{NO}_{2}$ oxidation may be slightly more important than indicated in Fig. 3. Our calculations (Fig. 5) suggest that $\mathrm{NO}_{2}$ oxidation accounts for $23 \%$ of heterogeneous sulfate formation at aerosol $\mathrm{pH}$ values between 7 and 8 . If sulfate formation on alkaline dust accounts for $9 \%$ of total sulfate formation and $\mathrm{NO}_{2}$ oxidation accounts for $23 \%$ of this sulfate formation pathway, then $\mathrm{NO}_{2}$ oxidation can account for up to $2 \%$ of total heterogeneous sulfate formation in Beijing, which still suggests $\mathrm{NO}_{2}$ oxidation is a minor pathway during wintertime Beijing haze events.

In addition to a model underestimate of the ozone oxidation pathway, a model underestimate of the $\mathrm{H}_{2} \mathrm{O}_{2}$ oxidation pathway may explain part of the modeled low bias in $\Delta^{17} \mathrm{O}\left(\mathrm{SO}_{4}^{2-}\right)$. The average modeled $\mathrm{H}_{2} \mathrm{O}_{2}$ concentrations during HPP and CP underestimate the observations (Ye et al., 2018) by up to an order of magnitude (Fig. S3c). Mao et al. (2013) proposed a $\mathrm{HO}_{2}-\mathrm{Cu}-\mathrm{Fe}$ catalytic mechanism for $\mathrm{H}_{2} \mathrm{O}_{2}$ production in the aerosol phase. In their mechanism, the uptake of $\mathrm{O}_{2}$ and subsequent heterogeneous reactions with $\mathrm{Cu}$ and $\mathrm{Fe}$ will lead to production of $\mathrm{H}_{2} \mathrm{O}_{2}$, when the molar ratio of dissolved $\mathrm{Cu}$ to $\mathrm{Fe}$ was $>0.1$. Ye et al. (2018) found that the molar ratio of dissolved $\mathrm{Cu}$ to $\mathrm{Fe}$ is $>0.1$ during moderately polluted days, suggesting the uptake of $\mathrm{HO}_{2}$ radicals on particles might be an important source of $\mathrm{H}_{2} \mathrm{O}_{2}$ during the winter in Beijing. We note, however, that an underestimate of modeled $\mathrm{H}_{2} \mathrm{O}_{2}$ cannot explain all of the discrepancy in $\Delta^{17} \mathrm{O}\left(\mathrm{SO}_{4}^{2-}\right)$, as sulfate formed from $\mathrm{H}_{2} \mathrm{O}_{2}$ oxidation $(0.7 \%$ ) is lower than the observed mean
$\Delta^{17} \mathrm{O}\left(\mathrm{SO}_{4}^{2-}\right)$ of $0.9 \%$. All other oxidation pathways yield $\Delta^{17} \mathrm{O}\left(\mathrm{SO}_{4}^{2-}\right)=0 \%$ and cannot explain the model's low bias in $\triangle^{17} \mathrm{O}\left(\mathrm{SO}_{4}^{2-}\right)$.

An increase in sulfate abundance of $9 \%$ from formation on alkaline dust is not enough to explain the remaining model underestimate in sulfate concentrations $(-40 \%)$ and SOR $(-28 \%)$ during HPP. Two recent studies suggested that hydroxymethane sulfonate (HMS) may be present in Chinese haze events and measured as sulfate via ion chromatography and HR-AMS (Moch et al., 2018; Song et al., 2019). HMS is formed via aqueous-phase oxidation via nucleophilic attack of $\mathrm{HSO}_{3}^{-}$and $\mathrm{SO}_{3}^{2-}$ on $\mathrm{HCHO}$. Moch et al. (2018) suggested that in-cloud formation of HMS could explain the low model bias in sulfate concentrations, while Song et al. (2019) suggested that heterogeneous formation of HMS on aerosol surfaces can explain up to one-third of the low model bias in their study. In the present study, as the organics were removed from the sample matrix prior to $\Delta^{17} \mathrm{O}\left(\mathrm{SO}_{4}^{2-}\right)$ analysis (Geng et al., 2013), suggesting that measured $\Delta^{17} \mathrm{O}\left(\mathrm{SO}_{4}^{2-}\right)$ does not have significant contributions from HMS. This will depend on the efficiency of HMS removal in $\mathrm{He}$ et al. (2018); previous work suggests that one of the two organic removal techniques employed $\left(\mathrm{H}_{2} \mathrm{O}_{2}\right.$ oxidation) does not remove HMS under atmospheric conditions (Munger et al., 1984, 1986). However, the presence of HMS in the sample matrix, if any, would lower measured $\Delta^{17} \mathrm{O}\left(\mathrm{SO}_{4}^{2-}\right)$, and any correction for this would increase the observed $\Delta^{17} \mathrm{O}\left(\mathrm{SO}_{4}^{2-}\right)$ and further increase the discrepancy between modeled and observed $\Delta^{17} \mathrm{O}\left(\mathrm{SO}_{4}^{2-}\right)$.

\section{Conclusion}

We have used a combination of observations and modeling of sulfate and $\mathrm{SO}_{2}$ concentrations and $\Delta^{17} \mathrm{O}\left(\mathrm{SO}_{4}^{2-}\right)$ to quantify sulfate production mechanisms in Beijing. We focus on the period of 17 October 2014-20 January 2015, when 10 heavy pollution periods (HPPs) were defined with observed $\mathrm{PM}_{2.5}$ concentrations $>150 \mathrm{\mu g} \mathrm{m}^{-3}$. The standard model simulation that only includes primary sulfate and sulfate formation from gas-phase oxidation by $\mathrm{OH}$ and in-cloud oxidation by $\mathrm{H}_{2} \mathrm{O}_{2}$ and $\mathrm{O}_{3}$ underestimates mean sulfate concentration by $65 \%$ and $\Delta^{17} \mathrm{O}\left(\mathrm{SO}_{4}^{2-}\right)$ by $50 \%$ during HPPs. Adding incloud oxidation catalyzed by transition metal ions (TMIs) and heterogeneous oxidation by $\mathrm{H}_{2} \mathrm{O}_{2}, \mathrm{O}_{3}, \mathrm{NO}_{2}$, and TMIs on aerosols can improve the model simulation of sulfate abundance and $\Delta^{17} \mathrm{O}\left(\mathrm{SO}_{4}^{2-}\right)$, with the model biases decreasing from $-65 \%$ to $-40 \%$ for sulfate and from $-50 \%$ to $-5 \%$ for $\Delta^{17} \mathrm{O}\left(\mathrm{SO}_{4}^{2-}\right)$ during HPP. Modeled heterogeneous sulfate production accounts for around $20 \%$ of total sulfate production. The model predicts that the TMI-catalyzed oxidation dominates heterogeneous sulfate production under the calculated aerosol $\mathrm{pH}$ of $\leq 5$; however, this reaction is highly uncertain due to limitations in our ability to assess modeled 
dissolved $\mathrm{Fe}(\mathrm{III})$ and $\mathrm{Mn}(\mathrm{II})$ concentrations. The modeled $\Delta^{17} \mathrm{O}\left(\mathrm{SO}_{4}^{2-}\right)$ is still biased low compared to observations, suggesting an underestimate of sulfate production by $\mathrm{O}_{3}$ oxidation. We hypothesize that sulfate aerosol production by $\mathrm{O}_{3}$ on externally mixed alkaline dust aerosol can explain at least part of the remaining discrepancy in $\Delta^{17} \mathrm{O}\left(\mathrm{SO}_{4}^{2-}\right)$. The $\Delta^{17} \mathrm{O}\left(\mathrm{SO}_{4}^{2-}\right)$ observations suggest that a fractional sulfate contribution of just $9 \%$ originating from $\mathrm{SO}_{2}$ oxidation on alkaline dust aerosol can explain the model discrepancy in $\Delta^{17} \mathrm{O}\left(\mathrm{SO}_{4}^{2-}\right)$. We calculate that sulfate formation on alkaline dust is dominated by $\mathrm{O}_{3}$ oxidation $(74 \%)$, followed by $\mathrm{NO}_{2}$ oxidation $(23 \%)$. The $\Delta^{17} \mathrm{O}\left(\mathrm{SO}_{4}^{2-}\right)$ observations combined with our model calculations indicate only a minor (2\%) role of heterogeneous sulfate formation via $\mathrm{NO}_{2}$ oxidation of $\mathrm{SO}_{2}$. Future studies will examine the impact of these heterogeneous $\mathrm{S}(\mathrm{IV})$ oxidation mechanisms on the regional and global sulfur budgets.

Data availability. For the model results please contact Becky Alexander (beckya@uw.edu) and Lin Zhang (zhanglg@pku.edu.cn). For isotope measurements please contact Zhouqing Xie (zqxie@ustc.edu.cn).

Supplement. The supplement related to this article is available online at: https://doi.org/10.5194/acp-19-6107-2019-supplement.

Author contributions. BA, LZ, JYS, and YXW designed the study. BA and LZ supervised the project. JYS performed model simulations and conducted analyses with the assistance of QJC, YXW, XL, VS, RVM, SP, SJS, and YZ. ZQX and PZH conducted the oxygen isotope measurements; YLS contributed the sulfate measurements. JYS, BA, and LZ wrote the paper. All authors contributed to the interpretation of the results and improvement of the paper.

Competing interests. The authors declare that they have no conflict of interest.

Acknowledgements. This work is supported by the National Key Research and Development Program of China (2017YFC0210102) and the National Natural Science Foundation of China (41475112). Jingyuan Shao acknowledges support from the China Scholarship Council (201606010049). Becky Alexander acknowledges support from NSF AGS 1644998 and Yuxuan Wang acknowledge support from NSF AGS 1645062. Zhouqing Xie acknowledges support from the National Natural Science Foundation of China (91544013). We thank Duncan Fairlie, Itushi Uno, Renyi Zhang, Havala O. T. Pye, Sakiko Ishino, Shohei Hattori, Youfan Chen, Jessica Haskins, Mi Zhou, Yuanhong Zhao for helpful discussions.
Review statement. This paper was edited by Eliza Harris and reviewed by two anonymous referees.

\section{References}

Alexander, B., Park, R. J., Jacob, D. J., Li, Q. B., Yantosca, R. M., Savarino, J., Lee, C. C. W., and Thiemens, M. H.: Sulfate formation in sea-salt aerosols: Constraints from oxygen isotopes, J. Geophys. Res., 110, D10307, https://doi.org/10.1029/2004jd005659, 2005.

Alexander, B., Park, R. J., Jacob, D. J., and Gong, S.: Transition metal-catalyzed oxidation of atmospheric sulfur: Global implications for the sulfur budget, J. Geophys. Res., 114, D02309, https://doi.org/10.1029/2008jd010486, 2009.

Alexander, B., Allman, D. J., Amos, H. M., Fairlie, T. D., Dachs, J., Hegg, D. A., and Sletten, R. S.: Isotopic constraints on the formation pathways of sulfate aerosol in the marine boundary layer of the subtropical northeast Atlantic Ocean, J. Geophys. Res., 117, D06304, https://doi.org/10.1029/2011jd016773, 2012.

Ammann, M., Cox, R. A., Crowley, J. N., Jenkin, M. E., Mellouki, A., Rossi, M. J., Troe, J., and Wallington, T. J.: Evaluated kinetic and photochemical data for atmospheric chemistry: Volume VI - heterogeneous reactions with liquid substrates, Atmos. Chem. Phys., 13, 8045-8228, https://doi.org/10.5194/acp13-8045-2013, 2013.

Beijing Environment Protection Agency: The report for 2017 air quality in Beijing, available at: http://sthjj.beijing.gov.cn (last access: 1 May 2019), 2018.

Calvert, J. G. and Stockwell, W. R.: Acid generation in the troposphere by gas-phase chemistry, Environ. Sci. Technol., 17, 428A-443A, https://doi.org/10.1021/es00115a727, 1983.

Chen, D., Liu, Z., Fast, J., and Ban, J.: Simulations of sulfatenitrate-ammonium (SNA) aerosols during the extreme haze events over northern China in October 2014, Atmos. Chem. Phys., 16, 10707-10724, https://doi.org/10.5194/acp-16-107072016, 2016.

Chen, Q., Geng, L., Schmidt, J. A., Xie, Z., Kang, H., Dachs, J., Cole-Dai, J., Schauer, A. J., Camp, M. G., and Alexander, B.: Isotopic constraints on the role of hypohalous acids in sulfate aerosol formation in the remote marine boundary layer, Atmos. Chem. Phys., 16, 11433-11450, https://doi.org/10.5194/acp-1611433-2016, 2016.

Chen, Q., Schmidt, J. A., Shah, V., Jaeglé, L., Sherwen, T., and Alexander, B.: Sulfate production by reactive bromine: Implications for the global sulfur and reactive bromine budgets, Geophys. Res. Lett., 44, 7069-7078, https://doi.org/10.1002/2017gl073812, 2017.

Chen, Q., Sherwen, T., Evans, M., and Alexander, B.: DMS oxidation and sulfur aerosol formation in the marine troposphere: a focus on reactive halogen and multiphase chemistry, Atmos. Chem. Phys., 18, 13617-13637, https://doi.org/10.5194/acp-1813617-2018, 2018.

Cheng, Y., Zheng, G., Wei, C., Mu, Q., Zheng, B., Wang, Z., Gao, M., Zhang, Q., He, K., Carmichael, G., Poschl, U., and Su, H.: Reactive nitrogen chemistry in aerosol water as a source of sulfate during haze events in China, Sci. Adv., 2, e1601530, https://doi.org/10.1126/sciadv.1601530, 2016. 
Chinese State Council: Atmospheric Pollution Prevention and Control Action Plan, available at: http://www.gov.cn/zwgk/2013-09/ 12/content_2486773.htm, last access: 12 January 2018.

Chuang, P. Y., Duvall, R. M., Shafer, M. M., and Schauer, J. J.: The origin of water soluble particulate iron in the Asian atmospheric outflow, Geophys. Res. Lett., 32, L07813, https://doi.org/10.1029/2004g1021946, 2005.

Clifton, C. L., Altstein, N., and Huie, R. E.: Rate constant for the reaction of nitrogen dioxide with sulfur (IV) over the $\mathrm{pH}$ range 5.3-13, Environ. Sci. Technol. 22, 586-589, https://doi.org/10.1021/es00170a018, 1988.

Colbeck, I. and Harrison, R.: Ozone-secondary aerosol-visibility relationships in North-West England, Sci. Total Environ., 34, 87100, https://doi.org/10.1016/0048-9697(84)90043-3, 1984.

Desboeufs, K. V., Losno, R., and Colin, J. L.: Factors influencing aerosol solubility during cloud processes, Atmos. Environ., 35, 3529-3537, https://doi.org/10.1016/s1352-2310(00)004726, 2001.

Desboeufs, K. V., Sofikitis, A., Losno, R., Colin, J. L., and Ausset, P.: Dissolution and solubility of trace metals from natural and anthropogenic aerosol particulate matter, Chemosphere, 58, 195203, https://doi.org/10.1016/j.chemosphere.2004.02.025, 2005.

Dominguez, G., Jackson, T., Brothers, L., Barnett, B., Nguyen, B., and Thiemens, M. H.: Discovery and measurement of an isotopically distinct source of sulfate in Earth's atmosphere, P. Natl. Acad. Sci. USA, 105, 12769-12773, https://doi.org/10.1073/pnas.0805255105, 2008.

Dubey, M. K., Mohrschladt, R., Donahue, N. M., and Anderson, J. G.: Isotope Specific Kinetics of Hydroxyl Radical $(\mathrm{OH})$ with Water $\left(\mathrm{H}_{2} \mathrm{O}\right)$ : Testing Models of Reactivity and Atmospheric Fractionation, J. Phys. Chem., 101, 1494-1500, https://doi.org/10.1021/jp962332p, 1997.

Fairlie, T. D., Jacob, D. J., and Park, R. J.: The impact of transpacific transport of mineral dust in the United States, Atmos. Environ., 41, 1251-1266, https://doi.org/10.1016/j.atmosenv.2006.09.048, 2007.

Fairlie, T. D., Jacob, D. J., Dibb, J. E., Alexander, B., Avery, M. A., van Donkelaar, A., and Zhang, L.: Impact of mineral dust on nitrate, sulfate, and ozone in transpacific Asian pollution plumes, Atmos. Chem. Phys., 10, 3999-4012, https://doi.org/10.5194/acp-10-3999-2010, 2010.

Fountoukis, C. and Nenes, A.: ISORROPIA II: a computationally efficient thermodynamic equilibrium model for $\mathrm{K}^{+}$. $\mathrm{Ca}^{2+}-\mathrm{Mg}^{2+}-\mathrm{NH}_{4}^{+}-\mathrm{Na}^{+}-\mathrm{SO}_{4}^{2-}-\mathrm{NO}_{3}^{-}-\mathrm{Cl}^{-}-\mathrm{H}_{2} \mathrm{O}$ aerosols, Atmos. Chem. Phys., 7, 4639-4659, https://doi.org/10.5194/acp-74639-2007, 2007.

Gao, M., Guttikunda, S. K., Carmichael, G. R., Wang, Y., Liu, Z., Stanier, C. O., Saide, P. E., and Yu, M.: Health impacts and economic losses assessment of the 2013 severe haze event in Beijing area, Sci. Total Environ., 511, 553-561, https://doi.org/10.1016/j.scitotenv.2015.01.005, 2015.

Gao, M., Carmichael, G. R., Saide, P. E., Lu, Z., Yu, M., Streets, D. G., and Wang, Z.: Response of winter fine particulate matter concentrations to emission and meteorology changes in North China, Atmos. Chem. Phys., 16, 11837-11851, https://doi.org/10.5194/acp-16-11837-2016, 2016.

Geng, G., Zhang, Q., Martin, R. V., Lin, J., Huo, H., Zheng, B., Wang, S., and He, K.: Impact of spatial proxies on the representation of bottom-up emission inventories: A satellite-based analysis, Atmos. Chem. Phys., 17, 4131-4145, https://doi.org/10.5194/acp-17-4131-2017, 2017.

Geng, L., Schauer, A. J., Kunasek, S. A., Sofen, E. D., Erbland, J., Savarino, J., Allman, D. J., Sletten, R. S., and Alexander, B.: Analysis of oxygen-17 excess of nitrate and sulfate at sub-micromole levels using the pyrolysis method, Rapid Commun. Mass Spectrom., 27, 2411-2419, https://doi.org/10.1002/rcm.6703, 2013.

Guieu, C., Duce, R., and Arimoto, R.: Dissolved input of manganese to the ocean: Aerosol source, J. Geophys. Res., 99, 18789-18800, https://doi.org/10.1029/94jd01120, 1994.

Guo, H., Weber, R. J., and Nenes, A.: High levels of ammonia do not raise fine particle $\mathrm{pH}$ sufficiently to yield nitrogen oxide-dominated sulfate production, Sci. Rep., 7, 12109, https://doi.org/10.1038/s41598-017-11704-0, 2017.

Guo, J., Wang, Y., Shen, X., Wang, Z., Lee, T., Wang, X., Li, P., Sun, M., Collett, J. L., Wang, W., and Wang, T.: Characterization of cloud water chemistry at Mount Tai, China: Seasonal variation, anthropogenic impact, and cloud processing, Atmos. Environ., 60, 467-476, https://doi.org/10.1016/j.atmosenv.2012.07.016, 2012.

Guo, S., Hu, M., Zamora, M. L., Peng, J., Shang, D., Zheng, J., Du, Z., Wu, Z., Shao, M., Zeng, L., Molina, M. J., and Zhang, R.: Elucidating severe urban haze formation in China, P. Natl. Acad. Sci. USA, 111, 17373-17378, https://doi.org/10.1073/pnas.1419604111, 2014.

Harris, E., Sinha, B., van Pinxteren, D., Tilgner, A., Fomba, K. W., Schneider, J., Roth, A., Gnauk, T., Fahlbusch, B., Mertes, S., Lee, T., Collett, J., Foley, S., Borrmann, S., Hoppe, P., and Herrmann, H.: Enhanced Role of Transition Metal Ion Catalysis During In-Cloud Oxidation of $\mathrm{SO}_{2}$, Science, 340, 727-730, https://doi.org/10.1126/science.1230911, 2013.

He, P., Alexander, B., Geng, L., Chi, X., Fan, S., Zhan, H., Kang, H., Zheng, G., Cheng, Y., Su, H., Liu, C., and Xie, Z.: Isotopic constraints on heterogeneous sulfate production in Beijing haze, Atmos. Chem. Phys., 18, 5515-5528, https://doi.org/10.5194/acp18-5515-2018, 2018.

Hendrick, F., Müller, J. F., Clémer, K., Wang, P., De Mazière, M., Fayt, C., Gielen, C., Hermans, C., Ma, J. Z., Pinardi, G., Stavrakou, T., Vlemmix, T., and Van Roozendael, M.: Four years of ground-based MAX-DOAS observations of HONO and $\mathrm{NO}_{2}$; in the Beijing area, Atmos. Chem. Phys., 14, 765-781, https://doi.org/10.5194/acp-14-765-2014, 2014.

Hennigan, C. J., Izumi, J., Sullivan, A. P., Weber, R. J., and Nenes, A.: A critical evaluation of proxy methods used to estimate the acidity of atmospheric particles, Atmos. Chem. Phys., 15, 2775 2790, https://doi.org/10.5194/acp-15-2775-2015, 2015.

Herrmann, H., Schaefer, T., Tilgner, A., Styler, S. A., Weller, C., Teich, M., and Otto, T.: Tropospheric aqueousphase chemistry: kinetics, mechanisms, and its coupling to a changing gas phase, Chem. Rev., 115, 4259-4334, https://doi.org/10.1021/cr500447k, 2015.

Hoffmann, M. R. and Calvert, J. G.: Chemical Transformation Modules for Eulerian Acid Deposition Models: Volume II, the Aqueous-phase Chemistry, Atmospheric Sciences Research Laboratory, Office of Research and Development, US Environmental Protection Agency, Boulder, Colorado, USA, 1985.

Holt, B. D., Kumar, R., and Cunningham, P. T.: Oxygen-18 study of the aqueous-phase oxidation of sulfur dioxide, Atmos. Envi- 
ron., 15, 557-566, https://doi.org/10.1016/0004-6981(81)901864, 1981.

Hua, Y., Cheng, Z., Wang, S., Jiang, J., Chen, D., Cai, S., Fu, X., $\mathrm{Fu}, \mathrm{Q}$., Chen, C., Xu, B., and Yu, J.: Characteristics and source apportionment of $\mathrm{PM}_{2.5}$ during a fall heavy haze episode in the Yangtze River Delta of China, Atmos. Environ., 123, 380-391, https://doi.org/10.1016/j.atmosenv.2015.03.046, 2015.

Huang, X., Song, Y., Zhao, C., Li, M., Zhu, T., Zhang, Q., and Zhang, X.: Pathways of sulfate enhancement by natural and anthropogenic mineral aerosols in China, J. Geophys. Res.-Atmos., 119, 14165-14179, https://doi.org/10.1002/2014jd022301, 2014.

Huie, R. E. and Neta, P.: Chemical behavior of $\mathrm{SO}_{3}^{-}$and $\mathrm{SO}_{5}^{-}$ radicals in aqueous solutions, J. Phys. Chem., 88, 5665-5669, https://doi.org/10.1021/j150667a042, 1984.

Hung, H. M. and Hoffmann, M. R.: Oxidation of Gas-Phase $\mathrm{SO}_{2}$ on the Surfaces of Acidic Microdroplets: Implications for Sulfate and Sulfate Radical Anion Formation in the Atmospheric Liquid Phase, Environ. Sci. Technol., 49, 13768-13776, https://doi.org/10.1021/acs.est.5b01658, 2015.

Ibusuki, T. and Takeuchi, K.: Sulfur dioxide oxidation by oxygen catalyzed by mixtures of manganese(II) and iron(III) in aqueous solutions at environmental reaction conditions, Atmos. Environ., 21, 1555-1560, https://doi.org/10.1016/0004-6981(87)90317-9, 1987.

Ishino, S., Hattori, S., Savarino, J., Jourdain, B., Preunkert, S., Legrand, M., Caillon, N., Barbero, A., Kuribayashi, K., and Yoshida, N.: Seasonal variations of triple oxygen isotopic compositions of atmospheric sulfate, nitrate, and ozone at Dumont d'Urville, coastal Antarctica, Atmos. Chem. Phys., 17, 37133727, https://doi.org/10.5194/acp-17-3713-2017, 2017.

Jacob, D. J.: Heterogeneous chemistry and tropospheric ozone, Atmos. Environ., 34, 2131-2159, https://doi.org/10.1016/s13522310(99)00462-8, 2000

Jenkins, K. A. and Bao, H.: Multiple oxygen and sulfur isotope compositions of atmospheric sulfate in Baton Rouge, Atmos. Environ., 40, 4528-4537, https://doi.org/10.1016/j.atmosenv.2006.04.010, 2006.

Jiang, H., Liao, H., Pye, H. O. T., Wu, S., Mickley, L. J., Seinfeld, J. H., and Zhang, X. Y.: Projected effect of 2000-2050 changes in climate and emissions on aerosol levels in China and associated transboundary transport, Atmos. Chem. Phys., 13, 7937-7960, https://doi.org/10.5194/acp-13-7937-2013, 2013.

Krotkov, N. A., McLinden, C. A., Li, C., Lamsal, L. N., Celarier, E. A., Marchenko, S. V., Swartz, W. H., Bucsela, E. J., Joiner, J., Duncan, B. N., Boersma, K. F., Veefkind, J. P., Levelt, P. F., Fioletov, V. E., Dickerson, R. R., He, H., Lu, Z., and Streets, D. G.: Aura OMI observations of regional $\mathrm{SO}_{2}$ and $\mathrm{NO}_{2}$ pollution changes from 2005 to 2015, Atmos. Chem. Phys., 16, 46054629, https://doi.org/10.5194/acp-16-4605-2016, 2016.

Lee, C. C. W. and Thiemens, M. H.: The $\delta^{17} \mathrm{O}$ and $\delta^{18} \mathrm{O}$ measurements of atmospheric sulfate from a coastal and high alpine region: A mass-independent isotopic anomaly, J. Geophys. Res.-Atmos., 106, 17359-17373, https://doi.org/10.1029/2000jd900805, 2001

Lee, C. C. W., Savarino, J., and Thiemens, M. H.: Mass independent oxygen isotopic composition of atmospheric sulfate: Origin and implications for the present and past atmo- sphere of Earth and Mars, Geophys. Res. Lett., 28, 1783-1786, https://doi.org/10.1029/2000gl011826, 2001.

Lee, C. W., Savarino, J., Cachier, H., and Thiemens, M.: Sulfur $\left({ }^{32} \mathrm{~S},{ }^{33} \mathrm{~S},{ }^{34} \mathrm{~S},{ }^{36} \mathrm{~S}\right)$ and oxygen $\left({ }^{16} \mathrm{O},{ }^{17} \mathrm{O},{ }^{18} \mathrm{O}\right)$ isotopic ratios of primary sulfate produced from combustion processes, Tellus B, 54, 193-200, https://doi.org/10.3402/tellusb.v54i3.16660, 2002.

Lee, Y. N. and Schwartz, S. E.: Kinetics of oxidation of aqueous sulfur (IV) by nitrogen dioxide, in: Kinetics of oxidation of aqueous sulfur (IV) by nitrogen dioxide, Precipitation scavenging, dry Deposition and resuspension, Proceedings of the Fourth International Conference, Santa Monica, California, 29 November3 December 1982, vol. 1, edited by: Pruppacher, H. R. and Slinn, W. G. N., Elsevier, New York, 453-470, 1983.

Lelieveld, J., Evans, J. S., Fnais, M., Giannadaki, D., and Pozzer, A.: The contribution of outdoor air pollution sources to premature mortality on a global scale, Nature, 525, 367-371, https://doi.org/10.1038/nature15371, 2015.

Li, G., Bei, N., Cao, J., Huang, R., Wu, J., Feng, T., Wang, Y., Liu, S., Zhang, Q., Tie, X., and Molina, L. T.: A possible pathway for rapid growth of sulfate during haze days in China, Atmos. Chem. Phys., 17, 3301-3316, https://doi.org/10.5194/acp17-3301-2017, 2017.

Li, L., Hoffmann, M. R., and Colussi, A. J.: Role of Nitrogen Dioxide in the Production of Sulfate during Chinese Haze-Aerosol Episodes, Environ. Sci. Technol., 52, 2686-2693, https://doi.org/10.1021/acs.est.7b05222, 2018.

Li, M., Zhang, Q., Kurokawa, J.-i., Woo, J.-H., He, K., Lu, Z., Ohara, T., Song, Y., Streets, D. G., Carmichael, G. R., Cheng, Y., Hong, C., Huo, H., Jiang, X., Kang, S., Liu, F., Su, H., and Zheng, B.: MIX: a mosaic Asian anthropogenic emission inventory under the international collaboration framework of the MICS-Asia and HTAP, Atmos. Chem. Phys., 17, 935-963, https://doi.org/10.5194/acp-17-935-2017, 2017.

Li, W., Zhou, S., Wang, X., Xu, Z., Yuan, C., Yu, Y., Zhang, Q., and Wang, W.: Integrated evaluation of aerosols from regional brown hazes over northern China in winter: Concentrations, sources, transformation, and mixing states, J. Geophys. Res., 116, D09301, https://doi.org/10.1029/2010jd015099, 2011.

Liu, H., Jacob, D. J., Bey, I., and Yantosca, R. M.: Constraints from ${ }^{210} \mathrm{~Pb}$ and ${ }^{7} \mathrm{Be}$ on wet deposition and transport in a global threedimensional chemical tracer model driven by assimilated meteorological fields, J. Geophys. Res.-Atmos., 106, 12109-12128, https://doi.org/10.1029/2000jd900839, 2001.

Liu, J. G., Xie, P., Wang, Y. S., Wang, Z. F., He, H., Liu, W.: Haze Observation and Control Measure Evaluation in Jing-JinJi (Beijing, Tianjin, Hebei) Area during the Period of the AsiaPacific Economic Cooperation (APEC) Meeting, Bull. Chin. Acad. Sci., 30, 368-377, https://doi.org/10.16418/j.issn.10003045.2015.03.011, 2015

Liu, M., Song, Y., Zhou, T., Xu, Z., Yan, C., Zheng, M., Wu, Z., $\mathrm{Hu}, \mathrm{M}$., Wu, Y., and Zhu, T.: Fine particle $\mathrm{pH}$ during severe haze episodes in northern China, Geophys. Res. Lett., 44, 5213-5221, https://doi.org/10.1002/2017gl073210, 2017.

Liu, Z., Hu, B., Wang, L., Wu, F., Gao, W., and Wang, Y.: Seasonal and diurnal variation in particulate matter $\left(\mathrm{PM}_{10}\right.$ and $\mathrm{PM}_{2.5}$ ) at an urban site of Beijing: analyses from a 9-year study, Environ. Sci. Pollut. Res. Int., 22, 627-642, https://doi.org/10.1007/s11356-014-3347-0, 2015. 
Ma, Q., Cai, S., Wang, S., Zhao, B., Martin, R. V., Brauer, M., Cohen, A., Jiang, J., Zhou, W., Hao, J., Frostad, J., Forouzanfar, M. H., and Burnett, R. T.: Impacts of coal burning on ambient $\mathrm{PM}_{2.5}$ pollution in China, Atmos. Chem. Phys., 17, 4477-4491, https://doi.org/10.5194/acp-17-4477-2017, 2017.

Mackie, D. S., Boyd, P. W., Hunter, K. A., and McTainsh, G. H.: Simulating the cloud processing of iron in Australian dust: pH and dust concentration, Geophys. Res. Lett., 32, L06809, https://doi.org/10.1029/2004g1022122, 2005.

Mao, J., Fan, S., Jacob, D. J., and Travis, K. R.: Radical loss in the atmosphere from $\mathrm{Cu}-\mathrm{Fe}$ redox coupling in aerosols, Atmos. Chem. Phys., 13, 509-519, https://doi.org/10.5194/acp-13-5092013, 2013.

Martin, L. R. and Hill, M. W.: The iron catalyzed oxidation of sulfur: Reconciliation of the literature rates, Atmos. Environ., 21, 1487-1490, https://doi.org/10.1016/0004-6981(67)90100-x, 1967.

Martin, L. R., Hill, M. W., Tai, A. F., and Good, T. W.: The iron catalyzed oxidation of sulfur(IV) in aqueous solution: Differing effects of organics at high and low pH, J. Geophys. Res., 96, 3085, https://doi.org/10.1029/90jd02611, 1991.

McArdle, J. V. and Hoffmann, M. R.: Kinetics and mechanism of the oxidation of aquated sulfur dioxide by hydrogen peroxide at low pH, J. Phys. Chem., 87, 5425-5429, https://doi.org/10.1021/j150644a024, 1983.

McCabe, J. R., Savarino, J., Alexander, B., Gong, S., and Thiemens, M. H.: Isotopic constraints on non-photochemical sulfate production in the Arctic winter, Geophys. Res. Lett., 33, L05810, https://doi.org/10.1029/2005gl025164, 2006.

Moch, J. M., Dovrou, E., Mickley, L. J., Keutsch, F. N., Cheng, Y., Jacob, D. J., Jiang, J., Li, M., Munger, J. W., Qiao, X., and Zhang, Q.: Contribution of Hydroxymethane Sulfonate to Ambient Particulate Matter: A Potential Explanation for High Particulate Sulfur During Severe Winter Haze in Beijing, Geophys. Res. Lett., 45, 11969-11979, https://doi.org/10.1029/2018g1079309, 2018.

Munger, J. W., Jacob, D. J., and Hoffmann, M. R.: The occurrence of bisulfite-aldehyde addition products in fog- and cloud water, J. Atmos. Chem., 1, 335-350, https://doi.org/10.1007/BF00053799, 1984.

Munger, J. W., Tiller, C., and Hoffmann, M. R.: Identification of hydroxymethanesulfonate in fog water, Science, 231, 247-249, https://doi.org/10.1126/science.231.4735.247, 1986.

Park, R. J., Jacob, D. J., Field, B. D., Yantosca, R. M., and Chin, M.: Natural and transboundary pollution influences on sulfate-nitrate-ammonium aerosols in the United States: Implications for policy, J. Geophys. Res., 109, D15204, https://doi.org/10.1029/2003jd004473, 2004.

Park, R. S., Lee, S., Shin, S. K., and Song, C. H.: Contribution of ammonium nitrate to aerosol optical depth and direct radiative forcing by aerosols over East Asia, Atmos. Chem. Phys., 14, 2185-2201, https://doi.org/10.5194/acp-14-2185-2014, 2014.

Patris, N., Cliff, S. S., Quinn, P. K., Kasem, M., and Thiemens, M. H.: Isotopic analysis of aerosol sulfate and nitrate during ITCT-2k2: Determination of different formation pathways as a function of particle size, J. Geophys. Res., 112, D23301, https://doi.org/10.1029/2005jd006214, 2007.

Philip, S., Martin, R. V., Snider, G., Weagle, C. L., van Donkelaar, A., Brauer, M., Henze, D. K., Klimont, Z., Venkataraman, C., Guttikunda, S. K., and Zhang, Q.: Anthropogenic fugitive, combustion and industrial dust is a significant, underrepresented fine particulate matter source in global atmospheric models, Environ. Res. Lett., 12, 044018, https://doi.org/10.1088/17489326/aa65a4, 2017.

Pozzer, A., de Meij, A., Pringle, K. J., Tost, H., Doering, U. M., van Aardenne, J., and Lelieveld, J.: Distributions and regional budgets of aerosols and their precursors simulated with the EMAC chemistry-climate model, Atmos. Chem. Phys., 12, 961-987, https://doi.org/10.5194/acp-12-961-2012, 2012.

Pye, H. O. T., Liao, H., Wu, S., Mickley, L. J., Jacob, D. J., Henze, D. K., and Seinfeld, J. H.: Effect of changes in climate and emissions on future sulfate-nitrate-ammonium aerosol levels in the United States, J. Geophys. Res.-Atmos., 114, D01205, https://doi.org/10.1029/2008jd010701, 2009.

Ravishankara, A. R.: Heterogeneous and Multiphase Chemistry in the Troposphere, Science, 276, 1058-1065, https://doi.org/10.1126/science.276.5315.1058, 1997.

Savarino, J. and Thiemens, M. H.: Analytical procedure to determine both $\delta^{18} \mathrm{O}$ and $\delta^{17} \mathrm{O}$ of $\mathrm{H}_{2} \mathrm{O}_{2}$ in natural water and first measurements, Atmos. Environ., 33, 3683-3690, https://doi.org/10.1016/S1352-2310(99)00122-3, 1999.

Savarino, J., Lee, C. C. W., and Thiemens, M. H.: Laboratory oxygen isotopic study of sulfur (IV) oxidation: Origin of the massindependent oxygen isotopic anomaly in atmospheric sulfates and sulfate mineral deposits on Earth, J. Geophys. Res.-Atmos., 105, 29079-29088, https://doi.org/10.1029/2000jd900456, 2000.

Schwartz, S. E.: Aqueous-phase reactions in cloud, American Chemical Society, Washington, D.C., 1987.

Seinfeld, J. H. and Pandis, S. N.: Atmospheric chemistry and physics: From air pollution to climate change, John Wiley \& Sons, New Jersey, USA, 2012.

Shen, X. H., Lee, T. Y., Guo, J., Wang, X. F., Li, P. H., Xu, P. J., Wang, Y., Ren, Y., Wang, W., Wang, T., Li, Y., Cam, S. A., and Collett, J. L.: Aqueous phase sulfate production in clouds in eastern China, Atmos. Environ., 62, 502-511, https://doi.org/10.1016/j.atmosenv.2012.07.079, 2012

Shen, Z., Sun, J., Cao, J., Zhang, L., Zhang, Q., Lei, Y., Gao, J., Huang, R.-J., Liu, S., Huang, Y., Zhu, C., Xu, H., Zheng, C., Liu, P., and Xue, Z.: Chemical profiles of urban fugitive dust $\mathrm{PM}_{2.5}$ samples in Northern Chinese cities, Sci. Total Environ., 569-570, 619-626, https://doi.org/10.1016/j.scitotenv.2016.06.156, 2016.

Shi, G., Xu, J., Peng, X., Xiao, Z., Chen, K., Tian, Y., Guan, X., Feng, Y., Yu, H., Nenes, A., and Russell, A. G.: pH of Aerosols in a Polluted Atmosphere: Source Contributions to Highly Acidic Aerosol, Environ. Sci. Technol., 51, 4289-4296, https://doi.org/10.1021/acs.est.6b05736, 2017.

Sofen, E. D., Alexander, B., and Kunasek, S. A.: The impact of anthropogenic emissions on atmospheric sulfate production pathways, oxidants, and ice core $\Delta^{17} \mathrm{O}\left(\mathrm{SO}_{4}^{2-}\right)$, Atmos. Chem. Phys., 11, 3565-3578, https://doi.org/10.5194/acp-113565-2011, 2011.

Song, S., Gao, M., Xu, W., Shao, J., Shi, G., Wang, S., Wang, Y., Sun, Y., and McElroy, M. B.: Fine-particle $\mathrm{pH}$ for Beijing winter haze as inferred from different thermodynamic equilibrium models, Atmos. Chem. Phys., 18, 7423-7438, https://doi.org/10.5194/acp-18-7423-2018, 2018.

Song, S., Gao, M., Xu, W., Sun, Y., Worsnop, D. R., Jayne, J. T., Zhang, Y., Zhu, L., Li, M., Zhou, Z., Cheng, C., Lv, Y., Wang, 
Y., Peng, W., Xu, X., Lin, N., Wang, Y., Wang, S., Munger, J. W., Jacob, D. J., and McElroy, M. B.: Possible heterogeneous chemistry of hydroxymethanesulfonate (HMS) in northern China winter haze, Atmos. Chem. Phys., 19, 1357-1371, https://doi.org/10.5194/acp-19-1357-2019, 2019.

Sun, Y., Wang, Z., Fu, P., Jiang, Q., Yang, T., Li, J., and Ge, X.: The impact of relative humidity on aerosol composition and evolution processes during wintertime in Beijing, China, Atmos. Environ., 77, 927-934, https://doi.org/10.1016/j.atmosenv.2013.06.019, 2013.

Sun, Y., Jiang, Q., Wang, Z., Fu, P., Li, J., Yang, T., and Yin, Y.: Investigation of the sources and evolution processes of severe haze pollution in Beijing in January 2013, J. Geophys. Res.-Atmos., 119, 4380-4398, https://doi.org/10.1002/2014jd021641, 2014.

Sun, Y., Du, W., Fu, P., Wang, Q., Li, J., Ge, X., Zhang, Q., Zhu, C., Ren, L., Xu, W., Zhao, J., Han, T., Worsnop, D. R., and Wang, Z.: Primary and secondary aerosols in Beijing in winter: sources, variations and processes, Atmos. Chem. Phys., 16, 8309-8329, https://doi.org/10.5194/acp-16-8309-2016, 2016.

Tan, Z., Lu, K., Jiang, M., Su, R., Dong, H., Zeng, L., Xie, S., Tan, Q., and Zhang, Y.: Exploring ozone pollution in Chengdu, southwestern China: A case study from radical chemistry to $\mathrm{O}_{3}$-VOC-NO $x$ sensitivity, Sci. Total Environ., 636, 775-786, https://doi.org/10.1016/j.scitotenv.2018.04.286, 2018.

Ullerstam, M., Johnson, M. S., Vogt, R., and Ljungström, E.: DRIFTS and Knudsen cell study of the heterogeneous reactivity of $\mathrm{SO}_{2}$ and $\mathrm{NO}_{2}$ on mineral dust, Atmos. Chem. Phys., 3, 2043-2051, https://doi.org/10.5194/acp-3-2043-2003, 2003.

Uno, I., Osada, K., Yumimoto, K., Wang, Z., Itahashi, S., Pan, X., Hara, Y., Yamamoto, S., and Nishizawa, T.: Importance of Long-Range Nitrate Transport Based on LongTerm Observation and Modeling of Dust and Pollutants over East Asia, Aerosol Air Qual. Res., 17, 3052-3064, https://doi.org/10.4209/aaqr.2016.11.0494, 2017.

Usher, C. R., Michel, A. E., and Grassian, V. H.: Reactions on Mineral Dust, Chem. Rev., 103, 4883-4940, https://doi.org/10.1021/cr020657y, 2003.

Van Der A, R. J., Mijling, B., Ding, J., Koukouli, M. E., Liu, F., Li, Q., Mao, H., and Theys, N.: Cleaning up the air: effectiveness of air quality policy for $\mathrm{SO}_{2}$ and $\mathrm{NO}_{x}$ emissions in China, Atmos. Chem. Phys., 17, 1775-1789, https://doi.org/10.5194/acp17-1775-2017, 2017.

Vicars, W. C. and Savarino, J.: Quantitative constraints on the ${ }^{17} \mathrm{O}$-excess $\left(\Delta^{17} \mathrm{O}\right)$ signature of surface ozone: Ambient measurements from $50^{\circ} \mathrm{N}$ to $50^{\circ} \mathrm{S}$ using the nitrite-coated filter technique, Geochim. Cosmochim. Ac., 135, 270-287, https://doi.org/10.1016/j.gca.2014.03.023, 2014.

Wang, G., Zhang, R., Gomez, M. E., Yang, L., Levy Zamora, M., Hu, M., Lin, Y., Peng, J., Guo, S., Meng, J., Li, J., Cheng, C., Hu, T., Ren, Y., Wang, Y., Gao, J., Cao, J., An, Z., Zhou, W., Li, G., Wang, J., Tian, P., Marrero-Ortiz, W., Secrest, J., Du, Z., Zheng, J., Shang, D., Zeng, L., Shao, M., Wang, W., Huang, Y., Wang, Y., Zhu, Y., Li, Y., Hu, J., Pan, B., Cai, L., Cheng, Y., Ji, Y., Zhang, F., Rosenfeld, D., Liss, P. S., Duce, R. A., Kolb, C. E., and Molina, M. J.: Persistent sulfate formation from London Fog to Chinese haze, P. Natl. Acad. Sci. USA, 113, 13630-13635, https://doi.org/10.1073/pnas.1616540113, 2016.

Wang, G., Zhang, F., Peng, J., Duan, L., Ji, Y., Marrero-Ortiz, W., Wang, J., Li, J., Wu, C., Cao, C., Wang, Y., Zheng, J., Se- crest, J., Li, Y., Wang, Y., Li, H., Li, N., and Zhang, R.: Particle acidity and sulfate production during severe haze events in China cannot be reliably inferred by assuming a mixture of inorganic salts, Atmos. Chem. Phys., 18, 10123-10132, https://doi.org/10.5194/acp-18-10123-2018, 2018.

Wang, Y., Zhang, Q. Q., He, K., Zhang, Q., and Chai, L.: Sulfate-nitrate-ammonium aerosols over China: response to 2000-2015 emission changes of sulfur dioxide, nitrogen oxides, and ammonia, Atmos. Chem. Phys., 13, 2635-2652, https://doi.org/10.5194/acp-13-2635-2013, 2013.

Wang, Y., Zhang, Q., Jiang, J., Zhou, W., Wang, B., He, K., Duan, F., Zhang, Q., Philip, S., and Xie, Y.: Enhanced sulfate formation during China's severe winter haze episode in January 2013 missing from current models, J. Geophys. Res.-Atmos., 119, 1042510440, https://doi.org/10.1002/2013jd021426, 2014.

Wang, Y. X., McElroy, M. B., Jacob, D. J., and Yantosca, R. M.: A nested grid formulation for chemical transport over Asia: Applications to CO, J. Geophys. Res.-Atmos., 109, D22307, https://doi.org/10.1029/2004jd005237, 2004.

Ye, C., Liu, P., Ma, Z., Xue, C., Zhang, C., Zhang, Y., Liu, J., Liu, C., Sun, X., and Mu, Y.: High $\mathrm{H}_{2} \mathrm{O}_{2}$ Concentrations Observed during Haze Periods during the Winter in Beijing: Importance of $\mathrm{H}_{2} \mathrm{O}_{2}$ Oxidation in Sulfate Formation, Environ. Sci. Technol. Lett., 5, 757-763, https://doi.org/10.1021/acs.estlett.8b00579, 2018.

Zhang, L. M., Gong, S. L., Padro, J., and Barrie, L.: A size-segregated particle dry deposition scheme for an atmospheric aerosol module, Atmos. Environ., 35, 549-560, https://doi.org/10.1016/s1352-2310(00)00326-5, 2001.

Zhang, L., Liu, L., Zhao, Y., Gong, S., Zhang, X., Henze, D. K., Capps, S. L., Fu, T.-M., Zhang, Q., and Wang, Y.: Source attribution of particulate matter pollution over North China with the adjoint method, Environ. Res. Lett., 10, 084011, https://doi.org/10.1088/1748-9326/10/8/084011, 2015.

Zhang, L., Shao, J., Lu, X., Zhao, Y., Hu, Y., Henze, D. K., Liao, H., Gong, S., and Zhang, Q.: Sources and Processes Affecting Fine Particulate Matter Pollution over North China: An Adjoint Analysis of the Beijing APEC Period, Environ. Sci. Technol., 50, 8731-8740, https://doi.org/10.1021/acs.est.6b03010, 2016.

Zhang, L., Chen, Y., Zhao, Y., Henze, D. K., Zhu, L., Song, Y., Paulot, F., Liu, X., Pan, Y., Lin, Y., and Huang, B.: Agricultural ammonia emissions in China: reconciling bottom-up and top-down estimates, Atmos. Chem. Phys., 18, 339-355, https://doi.org/10.5194/acp-18-339-2018, 2018.

Zhang, Q., Streets, D. G., Carmichael, G. R., He, K. B., Huo, H., Kannari, A., Klimont, Z., Park, I. S., Reddy, S., Fu, J. S., Chen, D., Duan, L., Lei, Y., Wang, L. T., and Yao, Z. L.: Asian emissions in 2006 for the NASA INTEX-B mission, Atmos. Chem. Phys., 9, 5131-5153, https://doi.org/10.5194/acp-9-5131-2009, 2009.

Zhang, R., Jing, J., Tao, J., Hsu, S. C., Wang, G., Cao, J., Lee, C. S. L., Zhu, L., Chen, Z., Zhao, Y., and Shen, Z.: Chemical characterization and source apportionment of $\mathrm{PM}_{2.5}$; in Beijing: seasonal perspective, Atmos. Chem. Phys., 13, 7053-7074, https://doi.org/10.5194/acp-13-7053-2013, 2013.

Zhang, X. Y., Gong, S. L., Shen, Z. X., Mei, F. M., Xi, X. X., Liu, L. C., Zhou, Z. J., Wang, D., Wang, Y. Q., and Cheng, Y.: Characterization of soil dust aerosol in China and its transport and distribution during 2001 ACE-Asia: 1. Net- 
work observations, J. Geophys. Res.-Atmos., 108, 4261-4274, https://doi.org/10.1029/2002jd002632, 2003.

Zhao, D., Song, X., Zhu, T., Zhang, Z., Liu, Y., and Shang, J.: Multiphase oxidation of $\mathrm{SO}_{2}$ by $\mathrm{NO}_{2}$ on $\mathrm{CaCO}_{3}$ particles, Atmos. Chem. Phys., 18, 2481-2493, https://doi.org/10.5194/acp18-2481-2018, 2018.

Zheng, B., Zhang, Q., Zhang, Y., He, K. B., Wang, K., Zheng, G. J., Duan, F. K., Ma, Y. L., and Kimoto, T.: Heterogeneous chemistry: a mechanism missing in current models to explain secondary inorganic aerosol formation during the January 2013 haze episode in North China, Atmos. Chem. Phys., 15, 2031-2049, https://doi.org/10.5194/acp-15-2031-2015, 2015.
Zheng, B., Tong, D., Li, M., Liu, F., Hong, C., Geng, G., Li, H., Li, X., Peng, L., Qi, J., Yan, L., Zhang, Y., Zhao, H., Zheng, Y., He, K., and Zhang, Q.: Trends in China's anthropogenic emissions since 2010 as the consequence of clean air actions, Atmos. Chem. Phys., 18, 14095-14111, https://doi.org/10.5194/acp-18-140952018, 2018. 